\title{
GÜNCEL KARARLAR VE SON GELİŞMELER IŞIĞINDA ICSID TAHKIMMINDE HAKEMİN REDDİ
}

\author{
Disqualification of Arbitrators in ICSID Arbitration in Light of Recent \\ Decisons and Developments
}

\section{Ahmet Sefa DİNLEYICI ${ }^{*}$}

TAAD

Yıl: 12 , Sayı: 48

Ekim 2021, (583-614)

\section{Makale Bilgisi}

Geliş Tarihi : 31.05.2021

Kabul Tarihi : 14.09.2021

Makale Türü : Araştırma

\section{$\underline{\text { Article Info }}$}

Received Date: 31.05.2021

Accepted Date: 14.09.2021

Article Type : Research

\section{ÖZET}

Tahkimde hakemlerin bağımsızlığını ve tarafsızlığını temin edecek düzenlemelerin başında hakemlerin ifşa yükümlülükleri ve hakemin reddi düzenlemesi gelmektedir. Bu kapsamda ise Uluslararası Yatırım Uyuşmazlıkları Çözüm Merkezi (ICSID) Tahkim Kurallarının diğer tahkim kurallarından birçok açıdan farklı olduğu göze çarpmaktadır. ICSID sistemindeki bu farkl1lıklar temelde hakemlerin ifşa yükümlerinin çok geniş olduğu ama buna karşı hakemin reddi standardının çok yüksek olduğu; bunlara bağlı olarak ret talep oranının yüksek, ret talebi kabul oranının ise çok düşük olduğu bir sonuç meydana getirmiştir. Ortaya çikan bu durum ICSID tahkimindeki hakemin reddi mekanizmasının işlevselliğinin sorgulanmasına yol açmıştır. Buradan hareketle yapılan bu çalışmada ICSID tahkiminde hakemin reddi konusu diğer tahkim kurallarıyla karşılaştırmalı olarak ele alınmış, ICSID sistemindeki eksiklikler ortaya konulmaya ve çözüm önerileri getirilmeye çalışılmıştır. Varılan en önemli sonuçlardan birisi ret standartlarının 2013 yılından günümüzde değin istikrarlı bir şekilde kolaylaştırıldığ 1 ve diğer tahkim normlarıyla uyumlulaştırıldığıdır. Ancak bu iyileşme ICSID sisteminde hakemin reddi mekanizmasını tek başına işlevsel hale getirmeye yeterli olmayıp; ret talebini değerlendirme usulünün de değiştirilmesi gerekmektedir. Ayrıca ret sebebi olarak sıklıkla ileri sürülen 'hakemin bir tarafça birden fazla kez atanması' veya 'hakemin uyuşmazlık konusunda akademik yayın yapması' gibi konularda ICSID yatırım tahkimi sisteminin ticari tahkimden farklı dinamikleri olduğu gözetilerek hakemin reddi konusunda buna göre karar verilmesi gerekmektedir.

Anahtar Kelimeler: Yatırım Tahkimi, Hakemin Reddi, ICSID, Ret Prosedürleri, IBA Kılavuzu, UNCITRAL Tahkim Kuralları

\begin{abstract}
Disclose obligations of arbitrators and disqualification of arbitrators are key issues in international arbitration. It is easily noticed that ICSID Arbitraiton Rules are different from other arbitration rules in very aspects regarding these issues. These differences basically brought low standards for disclose obligation
\end{abstract}

Bu makale Etik Kurul İznine tabi değildir.

* LL.M, Hukuk Müşaviri, Enerji ve Tabii Kaynaklar Bakanlığı Uluslararası Tahkim ve Alternatif Çözümler Daire Başkanlığ1, asafadinleyici@gmail.com, https://orcid.org/00000002-6538-4258. 
IIIIIIIIIII-

but high threshold for disqualification; high challenge rates of arbitrator but low success rates at those challenges. This situation caused ICSID arbitrator challenge mechanism's functionality to be questioned. Bearing in mind this situation, challenge of arbitrators issue in ICSID comparatively studied in this article and shortcomings and suggestions provided discusssed. Of the important results is that disqualification standards are being lowered from the 2013 consistently but this improvement is not sufficient to make ICSID challenge mechanism functional because there is also need to revise deciding authority where two unchallenged arbitrator decide on challenge issue. Besides, issues of "multiple appointments of arbitrator" or "issuing a publication regarding legal issue", which are frequently used by parties as disqualification reason, should be assessed considering the different dynamics of ICSID investment arbitration from commercial arbitration and decisions should regard those differences.

Keywords: Investment Arbitration, Disqualification of Arbitrator, ICSID, Challenge Procedures, IBA Guidelines, UNCITRAL Arbitration Rules

\section{GİRIŞ}

Tahkimin en önemli kurucu unsurlarından biri tarafların kendi hakemlerini seçebilmesidir. ${ }^{1}$ Söz konusu hakem seçiminde ise taraflar kendi tezlerini en iyi şekilde anlatabileceklerini düşündükleri hakemleri tercih ederler. ${ }^{2} \mathrm{Bu}$ bakımdan tahkim söz konusu olduğunda bir taraf için tezlerinin güçlü olup olmaması kadar hakem seçimi de önem arz etmektedir. Ancak tahkimin kurucu unsuru olarak kabul edilen hakemlerin taraflarca seçilmesi hususu kaçınılmaz olarak hakemlerin bağımsız ve tarafsız olmalarını engelleyecek çıkar çatışması risklerini ortaya çıkarır. Bu bakımdan hakemini, kendisini seçen taraftan başka tahkim yargılamalarında da görev alabilme düşüncesiyle bağlılık hissetmesi mümkün olup, bu durum çoğu zaman hakemlerin kendilerini seçen taraf lehine karar verebilmesi şeklinde de tezahür edebilmektedir. ${ }^{3}$ Ancak tüm bunlar hakemlerin tarafsız ve bağımsız olmalarını tamamen ortadan kaldıracak nitelikte hususlar değildir. Bu bağlamda tahkim yargılamalarında bağımsızlık ile en genel anlamda hakemin tarafla yahut taraf avukatıyla ekonomik, profesyonel yahut kişisel ilişkisinin olmaması; tarafsızlık ile de hakemin tahkimde dava konusuna veya tarafa karşı davanın esasıyla ilişkili olmayan harici bir sebepten dayalı ön yargılı olmayışı ifade edilir. ${ }^{4}$ Hakemlerin taraflar gözünde meşruiyetini ve cazibesini devam ettirebilmesi içinse hakemlerin söz konusu çıkar çatışmalarından uzak, tarafsız ve bağımsız olmalarının

\footnotetext{
Ziya Akıncı, Milletlerarası Tahkim (5.Baskı, Vedat Kitapçılık 2020) 585.

Alexis Mourre, 'Are unilateral appointments defensible? On Jan Paulsson's Moral Hazard in International Arbitration',

Kluwer Arbitration Blog, October 5, 2010, $5<\mathrm{http}: / /$ arbitrationblog.kluwerarbitration. com/2010/10/05/are-unilateral- appointments-defensible-on-jan-paulssons-moral-hazardin-international-arbitration/> erişim 30.05.2021.

3 Mustafa Serdar Özbek, 'Tahkim Yargılamasında Hakemin Reddi' (2021) 8(1) Türkiye Noterler Birliği Hukuk Dergisi 35, 40.

4 Hüseyin Akif Karaca, 'Milletlerarası Tahkimde Hakemin Reddi Sebebi Olarak Hakemin Tarafsızlığını ve Bağımsızlığını Ortadan Kaldıran Haller' (2015) 21(1) Marmara Üniversitesi Hukuk Fakültesi Hukuk Araştırmaları Dergisi 205, 207.
} 
sağlanması gerekmektedir.5 Tahkimin meşruiyetini korumak bakımından tarafsız ve bağımsızlığın önemli oluşu yanında, tahkim sonucu verilen hakem kararlarının kural olarak nihai oluşu, bir diğer deyişle temyiz incelemesine tabii olmayışı hakemlerin bağımsız ve tarafsız olmalarının önemini daha da arttırmaktadir. $^{6}$

Tüm bu sebeplerle tahkimde hakemlerin bağımsızlığını ve tarafsızlı̆̆ını temin edecek düzenlemeler gerekli olup, bu düzenlemelerin başında çalışmanın da konusunu oluşturan hakemlerin ifşa yükümlülükleri ve buna bağl1 olarak gündeme gelen hakemin reddi düzenlemesi gelmektedir. Tarafsılık, bağımsızlık, ifşa yükümü ve ret usullerine ilişkin düzenlemeler ise temel olarak tahkim kurumlarının ortaya koydukları tahkim kurallarında yahut Uluslararası Barolar Birliği gibi meslek örgütlerinin etik davranış kuralları olarak ortaya koydukları kılavuzlarda yer almaktadır.

Tahkim kurumlarının yahut genelde ad hoc tahkimde uygulama alanı bulan Birleşmiş Milletler Uluslararası Ticaret Hukuku Komisyonu (UNCITRAL) tahkim kuralları incelendiğinde hakemlerin bağımsızlığı, tarafsızlığı yahut ifşa yükümlerine ilişkin düzenlemelerde sadece çok temel standartların ortaya konulduğu, ancak ayrıntılı hükümlere yer verilmediği görülmektedir.? Hakemlerin bağımsızlığı, tarafsızlığı ve ifşa yükümlerinin ne olduğu, hangi standartların uygulanması gerektiği ve somut olarak hangi durumlarda hakemlerin bağımsızlıkların ve tarafsızlıklarının şüpheli hale geldiği gibi ayrıntılı düzenlemelerin ise bağlayıcı olmayan davranış kılavuzlarında yer aldığ1 görülmektedir. ${ }^{8}$ Tüm düzenlemeler genel olarak ele alındığında ise bunların esasında benzer standartlar üzerine kurulduğu, benzer ret usullerinin yer aldığı göze çarpmaktadır. Ancak hakemlerin bağımsızlığı, tarafsızlığı, ret usullerinin işletilmesi gibi düzenlemeler içinde Uluslararası Yatırım Uyuşmazlıkları Çözüm Merkezi (ICSID) Tahkim Kuralları` diğer tahkim kurallarından birçok açıdan farklı özellikler içermekte ve bu özellikler ICSID tahkimindeki hakemin reddi sisteminin farklı yönde gelişmesine ve birçok konuda eleştirilmesine yol açmaktadır.

$\mathrm{Bu}$ eleştirilerin başında ICSID tahkiminde hakemlerin bağımsız ve tarafsızlıklarına ilişkin standartların nasıl uygulanacağının net bir şekilde

5 Michael Hwang ve Kevin Lim, 'Issue Conflict in ICSID Arbitrations' (2011) 8(5) Transnational Dispute Management, 3.

6 Maria Nicole Cleis, The Independence and Impartiality of ICSID Arbitrators: Current Case Law, Alternative Approaches, and Improvement Suggestions (Brill 2017) 5.

7 Didem Kayalı, Milletlerarası Ticari Tahkimde Hakemlerin Bağımsızlığ ve Tarafsızlı̆̆ (Doktora Tezi, Ankara Üniversitesi Sosyal Bilimler Enstitüsü Özel Hukuk Anabilim Dali 2015) 5 .

ibid

$9 \quad$ ICSID Convention Arbitration Rules [2006] 
IIIIIIIIIII-

düzenlenmediği ve hakemlerin reddedilebilmelerinin pratikte neredeyse mümkün olmadığı eleştirileri gelmektedir. ${ }^{10}$ ICSID tahkim kurallarının hakemin reddinde ret talebinde bulunan tarafa çok ciddi bir yük getirmesi ve bağımsızlık ve tarafsızlık standartlarının net olmaması, tarafları taleplerinin kabulü ihtimalinin düşük olmasına rağmen daha fazla oranda ret talebinde bulunmaya; ret talepleri kabul edilmediğinde de tahkime karşı daha az güven duymalarına yol açmaktadır."

ICSID tahkimine başvuruların son yıllarda artmasına bağlı olarak tahkimde hakemlerin bağımsız ve tarafsız olmalarının garanti edilmesinin önemi ve bu bağlamda ICSID tahkiminde hakemin reddi sistemine karşı getirilen eleştiriler dikkate alınarak bu çalışmada ICSID Sözleşmesi ve Tahkim Kurallarına göre hakemin reddi konusu incelenmiştir. Bu inceleme sırasında esas olarak son y1llarda verilen en güncel ICSID hakem kararları, ICSID ve UNCITRAL Sekretaryaları tarafindan hazırlanan 'Yatırım Tahkiminde Görev Alacak Hakemler İçin Taslak Davranış Kuralları' (Taslak Davranış Kuralları)12 ve 'ICSID Tahkim Kuralları Revizyon Çalışmaları' (Tahkim Revizyon Çalışmaları) ${ }^{13}$ dikkate alınmıştır. Çalışmanın ilk bölümünde ICSID tahkiminde hakemin reddi usullerinin tam olarak diğer tahkim usullerinden hangi noktalarda ayrıştı̆̆ının daha net ortaya çıkarılabilmesi adına diğer tahkim kurallarında hakemin bağımsızlığı, tarafsızlığı, ifşa yükümü ve hakemin reddi düzenlemeleri genel hatlarıyla ortaya konulmuştur. İkinci bölümde ise ilk olarak ICSID tahkiminde hakemin reddi konusuna ilişkin kavramlar ele alınmış, hakemlerin bağımsızlığı, tarafsızlığı ve ifşa yükümlerine ilişkin standartların gelişimi ortaya konulmuş ve değerlendirilmiştir. Akabinde hakemin reddi süreci incelenmiş, bu bağlamda reddin hangi zaman aralığında yapılabileceği, ret talebinin hangi hakemlere karşı yapılabileceği, ret talebini kimin karara bağlayacağ 1 ve bu kararlara karşı herhangi bir itiraz yolu olup olmadığı gibi hususlar detaylıca ortaya konulmuş, ret süreci bakımından görülen eksiklikler tespit edilmekle birlikte yapılması gerekli somut iyileştirme önerileri sunulmuştur. Bölümün sonunda ise ICSID hakemin reddi kararlarında en fazla gündeme gelen ret sebepleri ele alınmış ve bu ret sebepleri konusunda nasıl karar verildiği gözlemlenmeye ve değerlendirilmeye çalışılmıştır.

Cleis (n 6) 254.

11 ibid 188

12 Code of Conduct for Adjudicators in Investor-State Dispute Settlement (version two) $<$ https://icsid.worldbank.org/sites/default/files/draft_code_of_conduct_v2_en_final.pdf $>$, erişim 30.05.2021.

13 ICSID, 'Proposals for Amendment of the ICSID Rules Working Paper 4' (2020), 1 $<$ https://icsid.worldbank.org/sites/default/files/amendments/WP_4_Vol_1_En.pdf $>$ erişim 30.05.2021 


\section{ICSID HARİCINDE ÖNDE GELEN DİĞER TAHKIMM KURALLARINA GÖRE HAKEMIN REDDİ}

ICSID tahkim kurallarından sonra yatırım tahkiminde en çok kullanılan tahkim kuralları UNCITRAL Tahkim Kurallarıdır. ${ }^{14}$ Genellikle taraflar arasında ad hoc tahkim öngörüldüğü durumlarda söz konusu UNCITRAL kuralları uygulama alanı bulur. ${ }^{15}$ UNCITRAL Tahkim Kuralları madde 11'de hakeme kendisine hakemlik teklif edildiğinde tarafsızlığı ve bağımsızlığ1 konusunda haklı şüphe oluşturabilecek durumları ifşa etme yükümlülüğü getirilmiştir. İfşa yükümlülügünü gerektiren haklı şüphenin tahkimin taraflarının gözünde mi yoksa makul ve objektif üçüncü kişide mi oluşması gerektiği konusunda ise netlik bulunmamaktadır. Ancak Uluslararası Ticaret Odası Tahkim Kuralları (ICC) madde 11(2), ${ }^{16}$ Stockholm Ticaret Odas1 (SCC) Tahkim Kuralları madde $18(2)^{17}$ veya Londra Uluslararası Tahkim Mahkemesi (LCIA) Tahkim Kuralları madde 5(4)'te ${ }^{18}$ benzer şekilde tarafların gözünde oluşacak haklı şüphenin aranması, UNCITRAL için de bu standardın kabul edilebileceğini göstermektedir. UNCITRAL ve diğer tahkim kurallarında bu ifşa yükümlülügünün tahkim süresince devam edeceği de kayıt altına alınmıştır. ${ }^{19}$ Söz konusu ifşa yükümlülügüu ise taraflarca atanmış olsun veya olmasın tüm hakemler için geçerlidir. ${ }^{20}$

UNCITRAL Tahkim Kuralları madde 12'ye göre taraflar, hakemin ifşa ettiği bilgilere yahut bunların dişındaki bir sebebe dayanarak hakemin tarafsız veya bağımsız olmadığını ileri sürerek hakemin reddini talep edebilir. Hakemin tarafsız veya bağımsız olmadığından hareketle reddi için söz konusu durumların haklı şüphe oluşturması gerekmektedir. ICC, SCC ve LCIA Tahkim Kurallarında da benzer şekilde hakemin reddi için hakemin bağımsızlığ 1 veya tarafsılılı̆ına ilişkin durumların haklı şüphe oluşturması gerekmektedir. ${ }^{21}$ Söz konusu düzenlemelerde haklı şüphenin ne anlama geldiğine yahut haklı şüphenin ret sebebi olabilmesi için kimde oluşması gerektiğine dair ayrıntılı düzenlemeler bulunmamaktadır.

14 Cleis (n 6) 112.

15 Karaca (n 4) 212.

16 ICC Arbitration Rules [2021]

17 Arbitration Rules of the Arbitration Institute of the Stockholm Chamber of Commerce [2017]

18 LCIA Arbitration Rules [2014]

19 UNCITRAL Arbitration Rules [2013] Madde 11; ICC Arbitration Rules Madde 11(3); Arbitration Rules of the Arbitration

Institute of the Stockholm Chamber of Commerce Madde 18(4); LCIA Arbitration Rules Madde 5(5).

20 Clyde Croft, Christopher Kee ve Jeff Waincymer, A Guide to UNCITRAL Arbitration Rules (Cambridge University Press 2013) 136.

21 LCIA Arbitration Rules Madde 10(1); Arbitration Rules of the Arbitration Institute of the Stockholm Chamber of Commerce Madde 19(1). 
IIIIIIIIIII-

Hakemin reddi talebinin ne sürede yapılacağ 1 konusunda söz konusu tahkim kurallarında çeşitli süreler öngörülmüş olup ret talebinin ret sebebinin öğrenilmesinden sonra belli süreler dahilinde yapılmış olması gerekmektedir. Buna bağlı olarak da süresinde yapılmayan ret talepleri kabul edilmemektedir. UNCITRAL madde 13(1)'e göre ret talebinin hakemin seçildiği tarafa bildirildiği tarihten veya ret sebebinin daha sonra öğrenilmesi halinde o tarihten itibaren 15 gün içinde yapılması gerekmektedir. SCC Tahkim Kurallarına göre bu süre 15 gün, ${ }^{22}$ LCIA Tahkim Kurallarına göre bu süre 14 gün, ${ }^{23}$ ICC Tahkim Kurallarına göre ise de 30 gündür. ${ }^{24}$ Bununla beraber tarafların kendi atadıkları hakemleri de reddedebilmeleri mümkün olmakla beraber bazı şartlara tabii tutulmuştur. Bu bakımdan UNCITRAL Tahkim Kuralları madde 12(2)'ye göre taraf, kendi atadığ hakemin reddini ancak gerçekleşen atamadan sonra öğrendiği sebeplere dayalı olarak yapabilecektir. SCC ve LCIA Tahkim Kurallarında da benzer şekilde düzenlemeler yer almakla beraber ICC Tahkim Kurallarında buna ilişkin bir sınırlama öngörülmemektedir. ${ }^{25}$

Hakemin öngörülen süreler içinde reddi sonrası kendiliğinden çekilmesi yahut tarafların anlaşması durumunda görevi sona erecektir. Ancak hakemin ret talebini kabul etmemesi de mümkün olup bu durumda kararı tahkim kurallarında belirlenen organlar verecektir. LCIA Tahkim Kurallarına göre hakemin reddi talebinde kararı LCIA Mahkemesi, ${ }^{26}$ SCC Tahkim Kurallara göre SCC Kurulu, ${ }^{27}$ ICC Tahkim Kurallarına göre ise de ICC Mahkemesi vermektedir. ${ }^{28}$ UNCITRAL Tahkim Kurallarına göre yürütülen tahkimlerde ise hakemin reddi talebine tahkim anlaşmasında belirlenen veya tarafların üzerinde anlaştı̆̆ kuruluş, eğer böyle bir anlaşma yoksa Daimî Hakemlik Mahkemesi Genel Sekreteri’nin belirlediği kuruluş karar vermektedir. ${ }^{29}$

ICSID haricindeki söz konusu tahkim kurallarına göre yapılan bazı kurumsal tahkim yargılamaları sırasında hakemin reddi talebi değerlendirilirken tahkimin yapıldığ 1 ülkenin ilgili düzenlemeleri de esas alınmaktadır. ${ }^{30} \mathrm{Bu}$ bağlamda LCIA tahkiminde hakemin reddi talebini değerlendirecek LCIA

22 Arbitration Rules of the Arbitration Institute of the Stockholm Chamber of Commerce Madde 19(3).

23 LCIA Arbitration Rules Madde 10(3).

24 ICC Arbitration Rules Madde 14(2).

25 LCIA Arbitration Rules Madde 10(3); Arbitration Rules of the Arbitration Institute of the Stockholm Chamber of Commerce Madde 19(2).

26 LCIA Arbitration Rules Madde 10(5).

27 Arbitration Rules of the Arbitration Institute of the Stockholm Chamber of Commerce Madde 19(5).

28 ICC Arbitration Rules Madde 14(3).

29 UNCITRAL Arbitration Rules Madde 13(4) ve Madde 6(4).

30 Audley Sheppard, 'Arbitrator Independence in ICSID Arbitration' in Christina Binder, Ursula Kriebaum, August Reinisch ve Stephan Wittich, International Investment Law for the 21st Century: Essays in Honour of Christoph Schreuer (Oxford University Press 2009) 136. 
Mahkemesi İngiliz Tahkim Yasası'n1, ${ }^{31}$ SCC tahkiminde hakemin reddini değerlendirecek SCC Kurulu İsveç Tahkim Yasası'nı da dikkate almaktadır. ${ }^{32}$ Yine ICSID sisteminden farklı olarak diğer tahkim yargılamalarında hakemin reddi taleplerine karşı hakem heyetlerince verilen kararlara karşı tahkimin yürütüldüğü ülke mahkemelerine başvuru hakkı bulunmaktadır. ${ }^{33}$

Son olarak üzerinde durulması gereken bir diğer nokta da hakemin reddi taleplerine ilişkin kararların gerekçeli olup olmaması ve yayımlanması hususudur. Bu kapsamda farklı tahkim yargılamalarında farklı uygulamalar olduğu göze çarpmakla beraber tüm tahkim yargılamalarında kararların gerekçeli olması ve yayımlanması yönünde bir eğilim olduğu da ayrıca tespit edilmektedir. ${ }^{34} \mathrm{Bu}$ bağlamda ICC tahkiminde hakemin reddine ilişkin kararlar 2015 yılından itibaren tarafların talebi üzerine gerekçeli olarak verilmeye ${ }^{35}$, kararlar ise zaman zaman özetler şeklinde yayımlanmaya başlamıştır. ${ }^{36}$ SCC tahkiminde hakemin reddine ilişkin bazı kararlar 2005 yılından itibaren yayımlanmaya, 2018 yılından itibaren de gerekçeli olmaya başlamıştır. ${ }^{37}$ LCIA tahkiminde ise kararların yayımlanması kararı 2006 yılında alınmış, 2011 yılında ilk defa 1996-2010 arasına ait 28 karar yayımlanmış olup, belli aralıklarla kararlar yayınlanmaya devam etmektedir. ${ }^{38}$

\section{ULUSLARARASI BAROLAR BİRLIĞİ (IBA) ULUSLARARASI TAHKIMDE ÇIKAR ÇATIŞMALARINA İLIŞKINN KILAVUZU}

IBA Uluslararası Tahkimde Çıkar Çatışmalarına İlişkin Kılavuz (IBA Kılavuzu) ilk olarak 2004 yılında tahkim kurumlarının ve diğer tahkim kurallarının hakemlerin bağımsızlığı, tarafsızlığı ve ifşa yükümlülüklerine ilişkin standartları ayrıntılı düzenlememiş olmasının getirdiği ihtiyacı karşılamak ve bu konudaki en yaygın uluslararası pratiği yansıtabilmek

31 Thomas W. Walsh ve Ruth Teitelbauma, 'The LCIA Court Decisions on Challenges to Arbitrators: An Introduction' (2011) 27(3) Arbitration International 283, 287.

32 Anja Ipp, Rodrigo Carè ve Valeryia Dubeshka, 'SCC Board Decisions on Challenges to Arbitrators 2016-2018' (2019) $4<$ https://sccinstitute.com/media/795278/scc-practice-note_ scc-decisions-on-challenges-to-arbitrators-2016-2018.pdf> erişim 30.05.2021.

33 James D. Fry ve Juan Ignacio Stampalija, 'Forged Independence and Impartiality: Conflicts of Interest of International Arbitrators in Investment Disputes' (2014) 30(2) Arbitration International 189, 209.

34 Gary B. Born, International Commercial Arbitration (3. Bask1, Wolters Kluwer 2020) 2062.

35 Loretta Malintoppi ve Alvin Yap, 'Challenges of Arbitrators in Investment Arbitration: Still Work in Progress?' in Katia Yannaca Small (ed), Arbitration Under International Investment Agreements: A Guide to Key Issues (2. Bask1 Oxford University Press 2018) 162.

36 Born (n 34) 1963.

37 Anina Liebkind, 'SCC Board Will Provide Reasoned Decisions on Arbitrator Challenges' (2017) $<$ https://globalarbitrationnews.com/scc-board-will-provide-reasoned-decisionsarbitrator-challenges/> erişim 30.05.2021

38 Malintoppi ve Yap (n 35) 166. 
IIIIIIIIIII-

amaciyla ortaya konulmuştur. ${ }^{39}$ Esasında başta ticari tahkimde görev alacak hakemlere ilişkin düzenlemeler getirmek için geliştirilmesi planlanırken daha sonra yatırım tahkiminde görev alacak hakemlere de uygulanacak şekilde geliştirilmiş olup, son hali 2014 yılında yayımlanmıştır. ${ }^{40}$

IBA Kılavuzu bağlayıcılığı olmayan bir düzenleme olmakla beraber tarafların tahkim anlaşmalarına dahil etmeleri ${ }^{41}$ yahut tahkim kurumlarının tahkim kuralları arasına dahil edilmesi suretiyle bağlayıcı nitelik kazanabilecek bir düzenlemedir. ${ }^{42}$ Ancak kılavuz en yaygın olarak tahkimde tarafların hakemleri reddederken atıfta bulunmaları yoluyla ve hakem heyetlerinin söz konusu kılavuzu faydalı kaynak olarak görmesi yoluyla kullanılmaktadır.

IBA K1lavuzu iki ana bölümden oluşmakta olup ilk bölümde hakemlerin bağımsız ve tarafsız olma yükümleri, çıkar çatışmaları, ifşa yükümü ve buna ilişkin şüphe halinde ifşa yükümü yahut ifşa etmenin zorunlu olarak hakemin reddi sebebi olmayacağ 1 gibi konular düzenlenmektedir. ${ }^{43}$ Hakemlerin çıkar çatışması oluşturabilecek durumlara ilişkin ifşa yükümüne ilişkin IBA Kılavuzunda bu bakımdan diğer tahkim kurallarında aranan objektif ve makul üçüncü kişi gözünde oluşacak haklı şüpheden daha düşük bir standart getirilmiş ve taraflar gözünde şüphe oluşturabilecek herhangi bir durumun hakemce ifşa edilmesi gerekliliği düzenlenmiştir. ${ }^{44}$

Kılavuzun ikinci bölümde ise söz konusu standartların pratikte uygulamasına ilişkin somut örnekler sınırlı sayıda olmayacak bir biçimde düzenlenmektedir. ${ }^{45}$ İlk olarak feragat edilemez kırmızı liste altında taraflar hakemin reddini istemeseler ve bu yönde anlaşsalar dahi hakemin çekilmesinin zorunlu olduğu haller sayılmıştır. ${ }^{46} \mathrm{Bu}$ bakımdan hakemin taraflardan biri veya davanın neticesiyle ekonomik bir çıkarının olması bu duruma örnek teşkil etmekte olup bu durum hakemin zorunlu olarak çekilmesini gerektirmektedir. Bunun yanında feragat edilebilir kırmızı liste, feragat edilemez kırmızı listedeki durumlar kadar ciddi olmasa da yine de çıkar çatışması oluşturabilecek ve bu yüzden hakemin göreve devamı için bu durumu ifşa etmesi ve tarafların buna rıza göstermesini gerektiren durumları kapsamakta olup, hakemin halihazırda

39 Cleis (n 6) 158.

40 Gabriel Bottini, 'Should Arbitrator Live on Mars - Challenge of Arbitrators in Investment Arbitration' (2009) 32 Suffolk Transnat'l L Rev 341, 346.

${ }_{41}$ KatiaFinkel, 'Arbitratorchallenges: apractical guide'(2020), $5<\mathrm{https}$ ://globalarbitrationnews. com/arbitrator-challenges- a-practical-guide/> erişim 30.05.2021

42 Malintoppi ve Yap (n 35) 167.

43 Phillip Landolt, 'The IBA Guidelines on Conflicts of Interest in International Arbitration: An Overview' (2005) 22(5) 409, 411-413.

44 Born (n 34) 1977.

45 Landolt (n 43) 412-413.

46 IBA Guidelines on Conflicts of Interest in International Arbitration (Guidelines) [2014] part 2 par 2 . 
taraflardan birini temsil etmesi bu kapsamda değerlendirilmektedir. ${ }^{47}$ Turuncu liste ise tarafların gözünde haklı şüphe oluşturabilecek ve bu yüzden hakemin ifşa etmesi gereken durumları kapsamakla birlikte söz konusu ifşa zorunlu olarak hakemin reddini gerektirmemektedir. ${ }^{48}$ Son olarak düzenlenen yeşil liste ile objektif olarak çıkar çatışması oluşturmayacak ve bu bakımdan hakem için ifşa yükümü gerektirmeyen durumlar listelenmiş olup, hakemin daha önce uyuşmazlık konusu ile ilgili hukuki konularda görüşünü yayınlamış olması örnek olarak bu kapsama girmektedir. ${ }^{49}$

IBA Kılavuzunun en avantajlı yönü tahkim kuralları içerisinde somut ve pratikte uygulanabilir düzenlemeler getirmesidir..$^{50}$ Özellikle k1lavuzun ikinci bölümünde somut örnekler üzerinden sınırlı sayıda olmayacak biçimde çıkar çatışması oluşturacak ve çıkar çatışması oluşturabilecek durumların, bunun yanında çıkar çatışması oluşturmayacak ve hakemler bakımından 'güvenli bölge' olarak değerlendirilebilecek durumların belirtilmesi hakemin reddi konusunda çok önemli kolaylıklar sağlamaktadır. Kılavuz bu özellikleri nedeniyle tahkim alanında en fazla kullanılan ikinci kılavuz durumunda bulunmaktadır. ${ }^{51}$ Özellikle yayınlanan bir çalışmada ICC tahkim davalarında 2004-2009 yılları arasinda incelenen 187 hakemin reddi talebinin 109'unda IBA Kılavuzuna atıf yapıldığ ${ }_{1}$ tespit edilmiştir. ${ }^{52}$ IBA Kılavuzu ICSID, SCC ve LCIA tahkimlerinde de benzer biçimde taraflarca sıklıkla kullanılmaktadır. ${ }^{53}$

Kılavuzun avantajlı yönlerinin dışında bazı eksik yönleri de bulunmaktadır. Bu eksikliklerin başında hakemlerin ifşa yükümü eşiğinin çok düşük seviyede belirlenmesi ve bu sebeple hakemlerin neredeyse bütün şüpheli olabilecek durumları ifşa ile yükümlü tutulmaları gösterilebilir. Hakemlerin neredeyse her şüpheli durumu ifşa etmeleri doğal olarak avukatları, ifş̧a edilen sebeplere dayanarak hakemin reddi talebinde bulunmaya itmekte ve bu durum hakemin reddi taleplerini arttırarak tahkim sürelerini uzatmaktadır. ${ }^{54}$ Bunun yanında kılavuzun eksiklik olarak değerlendirilebilecek bir diğer yönü de çalışmanın son bölümünde ICSID tahkim davalarında hakemin reddi konusu incelenirken

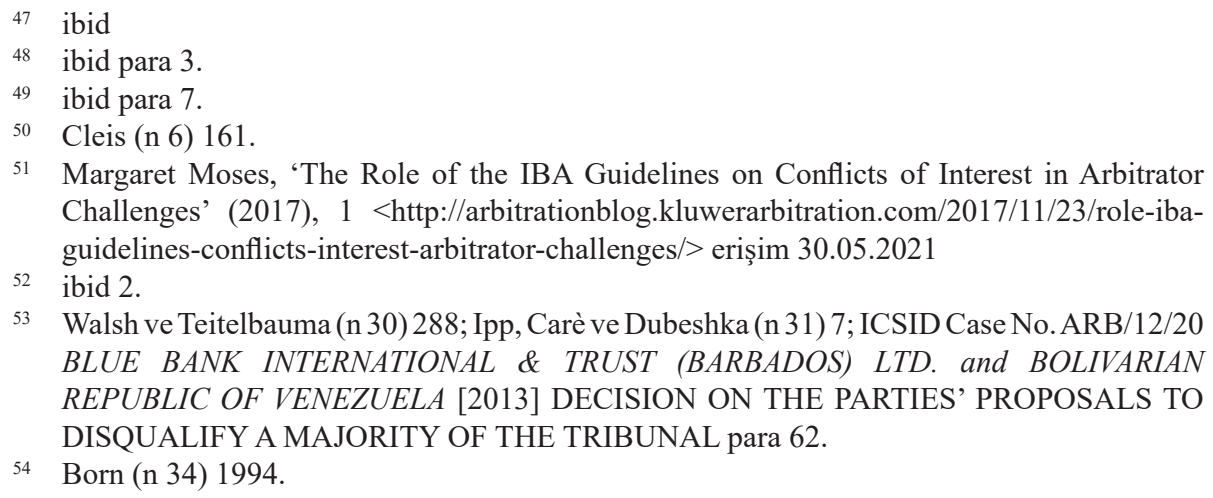

53 Walsh ve Teitelbauma (n 30) 288; Ipp, Carè ve Dubeshka (n 31) 7; ICSID Case No. ARB/12/20 BLUE BANK INTERNATIONAL \& TRUST (BARBADOS) LTD. and BOLIVARIAN REPUBLIC OF VENEZUELA [2013] DECISION ON THE PARTIES' PROPOSALS TO DISQUALIFY A MAJORITY OF THE TRIBUNAL para 62.

54 Born (n 34) 1994. 
IIIIIIIIIII-

de ortaya çıkan kılavuzun ortaya koyduğu hakemin tarafsızlığı, bağımsızlığı ve ifşa yükümüne ilişkin standartların her zaman doğrudan yatırım tahkimi hakemlerine uygulanmasının yarattığı olumsuzluklardır. Bilhassa, 'hakemlerin tekrar atanması' yahut 'hakemlerin hukuki uyuşmazlık konusunda görüş bildirmesi' gibi konularda Kılavuzda düzenlenen standartlar yatırım tahkiminde hakemin reddi taleplerine uygulandığında etkili sonuçlar ortaya çıkmamaktadır..$^{55}$

\section{ICSID TAHKIMINDE HAKEMIN REDDİ}

\section{A. Genel Kavramlar}

ICSID tahkiminde hakemin reddi ICSID Sözleşmesi madde 57'de düzenlenmektedir. Buna göre temelde hakemin reddi için iki farklı sebep bulunmakta olup, bunlardan ilki; hakemin sözleşmenin 14(1) maddesinde aranan yüksek ahlak sahibi oluş, hukuki ve belirtilen diğer konularda yetkinlik ve bağımsız yargılama yapabileceğine güvenilme gibi niteliklerden açık bir biçimde yoksun olması, ikinci sebep de Sözleşmenin 4. kısmının 2. bölümünde hakemin uyruğu ile ilgili düzenlemelere aykırılıktır. ICSID Sekretaryası hakem seçimi sırasında hakemlerin uyruğu konusunda taraflara yardımcı olduğu ve gerekli şartları kontrol ettiği için bu sebebe dayalı olarak hakemin reddi talebi uygulamada nadir olarak karşılaşılmaktadır. ${ }^{56}$ Uygulamada hakemin reddi taleplerinin daha çok madde 14(1)'e göre, daha da spesifik olarak ilgili şartlardan, 'hakemin bağımsız yargılama yapabileceğine olan güven' niteliğine ilişkin yapıldığı görülmektedir. ${ }^{57}$ Her ne kadar ICSID Sözleşmesi'nin İngilizce metninde, aranan nitelikler bakımından hakemin bağımsızlı̆̆ 1 kavramı tek başına yer alsa da sözleşmenin aynı şekilde geçerli kabul edilen İspanyolca ve Fransızca versiyonlarında bağımsızlık ve tarafsızlık kavramları birlikte yer aldığ ve bu metinler aynı şekilde geçerliliğe sahip oldukları için hakemlerin bağımsızlık ve tarafsızlık niteliklerine aynı anda sahip olmaları gerektiği doktrinde kabul görmektedir. ${ }^{58}$

ICSID tahkim kurallarını diğer tahkim kurallarından hakemin reddi konusunda ayıran en belirgin noktalardan biri, hakemin reddi için bağımsızlığına ve tarafsızlığına ilişkin eksikliklerin 'açık veya çok belirgin' (manifest) şekilde olmasının aranmasıdır. ${ }^{59}$ Söz konusu ifade bazı hakem heyetlerince

55 Cleis (n 6) 168-169.

56 Christoph H. Scheurer ve diğerleri, The ICSID Convention: A Commentary (2. Bask1, Cambridge University Press 2009) 1208.

57 Meg Kinnear, 'Challenge of Arbitrators at ICSID-An Overview' (2014) 108 The Effectiveness of International Law 412, 414.

58 Malintoppi ve Yap (n 35) 155.

59 Convention on the Settlement of Investment Disputes Between States and Nationals of Other States (ICSID Convention) [1966] Madde 57. 
hakemin reddi için gerekli eşiğin yükseltilmesi gerektiği şeklinde anlaşılmış ve bunun yansıması olarak ICSID tahkiminde hakemin reddi talebinin kabulü diğer tahkimlere göre çok ciddi oranda zorlaştırılmıştır. ${ }^{60}$ Bununla birlikte söz konusu şart ICSID tahkiminde görülen hakemin reddi taleplerinin diğer tahkim sistemlerinden ayrışmasını beraberinde getirmiş ve bu sebeple yoğun bir biçimde eleştirilmiş ve değiştirilmesi gerektiği ileri sürülmüştür. ${ }^{61} \mathrm{Bu}$ bakımdan önemle belirtilmesi gereken husus ICSID Sözleşmesi'nin hazırlığ sürecinde 'açık bir biçimde' ibaresine bazı hakem heyetlerince yapıldı̆̆ gibi ilgili niteliklerin eksikliğinin ciddi oluşu şeklinde mana verilmesini gerektirecek bir düşünce olmadığıdır. ${ }^{62}$

ICSID tahkiminde hakemin reddi taleplerine ilişkin verilen kararlara bakıldığında da 'açık bir biçimde' ibaresine birbirine tamamen zıt manalar verildiği görülmekte ve durumun kararları ciddi bir biçimde etkilediği tespit edilmektedir. ${ }^{63}$ Hakemin reddi konusunda ICSID bakımından verilen ilk karar olan Amco v Indonesia kararında hakemin reddi için bağımsızlık ve tarafsızlığa ilişkin eksikliklerin 'açık bir biçimde' ifadesinden hareketle 'ciddi ve ağır olması' gerektiği kabul edilmiştir. ${ }^{64}$ Daha sonra gelen Vivendi $v$ Argentina 1 kararında 'açık biçimde' ibaresinin daha yükssek bir eşik oluşturmadığı, diğer tahkimlerde olduğu gibi hakemin tarafsızlığı ve bağımsızlığına ilişkin haklı veya makul şüphenin sadece ortaya çıkmasının hakemin reddi için yeterli olduğu kabul edilmiştir. ${ }^{65}$ Ancak Vivendi kararında benimsenen yaklaşım daha sonra verilen kararlarda terk edilmiş ve tekrar Amco kararında kabul edilen ve bağımsızlık ve tarafsızlığa ilişkin eksikliğin çok ciddi olması gerekliliğini arayan yaklaşıma geri dönülmüştür. ${ }^{66} 2013$ y1lına gelindiğinde ise Bluebank $v$ Venezuela tahkim davasında hakemin reddi talebinde Vivendi' de benimsenen haklı veya makul şüphenin ortaya çıkmasının yeterliliği yaklaşımı tekrar benimsenmiş ve ICSID tarihinde ilk defa hakemin reddi talebi kabul edilmiştir. ${ }^{67}$

60 Fry ve Stampalija (n 33) 210.

61 ibid 191.

62 Karel Daele, Challenge and Disqualification of Arbitrators in International Arbitration (Kluwer Law International 2012) 233.

63 Malintoppi ve Yap (n 35) 156.

64 Fry ve Stampalija (n 33) 210.

65 CSID Case No. ARB/97/3 Compañia de Aguas del Aconquija S.A. \& Vivendi Universal v. Argentine Republic DECISION ON THE CHALLENGE TO THE PRESIDENT OF THE COMMITTEE [2001] para 25

66 Fry ve Stampalija (n 33) 211-242.

67 CSID Case No. ARB/12/20 BLUE BANK INTERNATIONAL \& TRUST (BARBADOS) LTD. and BOLIVARIAN REPUBLIC OF VENEZUELA [2013] DECISION ON THE PARTIES' PROPOSALS TO DISQUALIFY A MAJORITY OF THE TRIBUNAL para 59. 
IIIIIIIIIII-

2013 y1lında Bluebank kararıyla başlayan önemli değişim, nadiren aksi yönde çıkan kararlar olsa da, ${ }^{68}$ istikrarlı bir biçimde günümüze değin uygulanmaya devam etmekte olup, ${ }^{69}$ bu bakımdan ICSID tahkiminde hakemin reddi standardı ile diğer tahkimlerde aranan hakemin reddi standardı arasındaki ayrım ortadan kalkmış, ICSID tahkimindeki hakemin reddi standardı uluslararası standartlarla uyum sağlamış ve hakemin reddi daha kolaylaşmış görünmektedir. ${ }^{70}$ Söz konusu standardın istikrarlı olarak uygulanması zamanla hakemin reddi taleplerinin inceleme sürelerini kısaltacak, standartların net olmamasından kaynaklı açıkça dayanaktan yoksun hakemin reddi taleplerini azaltacak ve nihayetinde diğer tahkimlerde olduğu gibi daha az yapılan ama daha fazla kabul oranı olan hakemin reddi taleplerini beraberinde getirecektir. ${ }^{71}$ Bu bakımdan ICSID tahkiminde uluslararası normlara uygun olacak biçimde son yıllarda benimsenen görüş olumlu bir gelişme olmakla birlikte ICSID tahkimi uyuşmazlıklarının ekonomik değerinin ticari tahkime göre daha fazla oluşu ve ICSID tahkimi sonucu verilen kararların yeniden gözden geçirilebilme imkanlarının çok daha sınırlı oluşu karşısında hakemin bağımsızlığı ve tarafsızlığı çok daha fazla önemi haiz olduğu için hakemin reddi eşiğinin taraflar açısından daha da düşürülmesi daha tercih edilebilir gözükmektedir. ${ }^{72}$

Hakemlerin tarafsızlığının ve bağımsızlığının sorgulanması ve dolayısıyla ret taleplerinin gerçekleştirilmesi büyük ölçüde hakemlerin ifşa yükümleriyle ilgilidir. Bu bakımdan ICSID Tahkim Kuralları madde 6(2)'ye göre hakemlerin seçildikten sonra başlayan ifşa yükümleri tahkim süreci boyunca devam etmektedir. İfşa yükümlülügünü düzenleyen ilgili hükme göre hakemler varsa taraflarla olan mevcut veya geçmiş ilişkilerini ve 2006 y1lı değişiklikleri ile hakemin bağımsızlığının taraflarca sorgulanmasına yol açabilecek herhangi bir durumu ifşa etmek zorundadırlar. 2006 yılında hakemlerin ifşa yükümlülükleri

68 ICSID Case No. ARB/19/4 CANEPA GREEN ENERGY OPPORTUNITIES I, S.Á R.L. AND CANEPA GREEN ENERGY OPPORTUNITIES II, S.A' R.L. CLAIMANTS and KINGDOM OF SPAIN [2019] DECISION ON THE PROPOSAL TO DISQUALIFY MR. PETER REES QC para 50.

69 ICSID Case No. ARB/19/20 AYAT NIZAR RAJA SUMRAIN and STATE OF KUWAIT [2020] DECISION ON THE CLAIMANTS' PROPOSAL TO DISQUALIFY PROF. ZACHARY DOUGLAS AND MR. V. V. VEEDER para 106; ICSID Case No. ARB/17/5 EUGENE KAZMIN and REPUBLIC OF LATVIA [2020] DECISION ON THE PROPOSAL TO DISQUALIFY ALL MEMBERS OF THE TRIBUNAL para 72; ICSID Case No. ARB/15/45 LANDESBANK BADEN- WÜRTTEMBERG ET AL. and KINGDOM OF SPAIN [2020] DECISION ON THE SECOND PROPOSAL TO DISQUALIFY ALL MEMBERS OF THE TRIBUNAL para 130.

70 Karel Daele, 'Saint Gobain v Venezuela and Blue Bank v Venezuela: The Standard for Disqualifying Arbitrators Finally Settled and Lowered' (2014) 29(2) ICSID Review 296, 305.

71 Born (n 34) 1994.

72 Daele (n 67) 266. 
ile ilgili yapılan bu değişiklikler ifşa kapsamını genişletmiş ${ }^{73}$ ve ICSID hakemlerinin ifşa standardını IBA Kılavuzundaki standarda yaklaştırmıştır. Hakemlerin ifşa yükümlülüklerinin genişlemesi ICSID tahkiminde hakemin reddi taleplerinin önemli ölçüde artmasını beraberinde getirmiş ve bu bakımdan tahkimde hakemin reddi talebinin yapılma oranının ICSID tahkiminde diğer tahkimlerden daha fazla olmasına yol açmıştır. ${ }^{74}$

ICSID Tahkim Kuralları ile düzenlenen ifşa yükümlülükleri Taslak Davranış Kuralları ile IBA Kılavuzuna benzer şekilde detaylandırılmıştır. Bu bakımdan Taslak Davranış Kuralları hakemlerin ifşa yükümlülüklerini netleştirmek bakımından önemli bir çalışmadır. ${ }^{75}$ Söz konusu çalışmanın henüz taslak aşamasında olmasına rağmen hakemin reddi taleplerinde atıf yapılmaya başlanması ${ }^{76}$ söz konusu çalışmanın ne derece önemli bir ihtiyaca tekabül ettiğini açıkça ortaya koymaktadır. Ancak söz konusu Taslak Davranış Kurallarında, ICSID tahkimde görev alacak hakemler bakımından IBA Kılavuzunun yeşil listede düzenlediği gibi hakemlere ifş̧a etmelerine gerek olmayan somut durumları gösteren örneklerin bulunmaması bir eksiklik olarak göze çarpmaktadır. Bu bakımdan örneğin Taslak Davranış Kurallarında hakemin, ICSID tahkiminde birçok bilginin internet sitesinden de paylaşılması dikkate alınarak, herkesçe bilinen bilgileri paylaşma zorunluluğun olmadığ 1 şeklinde yapılabilecek bir düzenleme hakemleri gereksiz ifşa yükümünden kurtarabilirdi.

ICSID Tahkim Kuralları açısından hakemlerin ifşa yükümüne ilişkin belirtilmesi gereken son husus da ifşa etmemenin sonuçlarıdır. ICSID tahkimindeki hakemin reddi taleplerine ilişkin kararlar incelendiğinde ifşa edilmesi gereken bir hususun ifşa edilmemiş olmasının zorunlu olarak hakemin bağımsız ve tarafsız olmadığı sonucunu doğurmayacağının kabul edildiği göze çarpmaktadır. ${ }^{77} \mathrm{Bu}$ gibi durumlarda talebi inceleyen hakemler asıl olarak neyin ifşa edilmediği, ifşa edilmeyen bilginin kamunun erişimine açık olup olmadığı, ifşa etmemenin iyi niyetle yapılıp yapılmadığı gibi hususlara dikkat etmektedirler. ${ }^{78}$ Örneğin Tidewater $v$ Venezuela tahkim yargılamasında hakem

73 CSID Secretariat, 'Suggested Changes to the ICSID Rules and Regulations' (2005), 12 $<$ https://icsid.worldbank.org/sites/default/files/Suggested $\% 20$ Changes $\% 20$ to $\% 20$ the $\% 20$ ICSID\%20Rules\%20and\%20Regulations.pdf/> erişim 30.05.2021

74 Finkel (n 41) 8.

75 Açelya Şahin ve Güray Özsu, 'Yatırımcı Devlet Uyuşmazlık Çözüm Sistemi'nin (ISDS) Reformu Bakımından Önemli Bir Adım: Taslak Etik Kurallar' (2021) 12(46) Türkiye Adalet Akademisi Dergisi 477, 495.

76 CSID Case No. ARB/15/45 LANDESBANK BADEN-WÜRTTEMBERG ET AL. and KINGDOM OF SPAIN [2020] DECISION ON THE SECOND PROPOSAL TO DISQUALIFY ALL MEMBERS OF THE TRIBUNAL para 70.

77 Cleis (n 6) 20.

78 Daele (n 67) 453. 
IIIIIIIIII!

Brigette Stern'in hangi tahkim davalarında yer aldığının bilindiği, bunun Tahkim Kuralları madde 6(2)'ye göre yine de ifşa edilmesi gerektiği halde ifşa edilmemiş olmasının, söz konusu bilginin herkesçe biliniyor olması nedeniyle hakemin bağımsızlığını ve tarafsızlığını şüpheye düşürecek nitelikte olmadığı belirtilmiştir. ${ }^{79}$

İfşa yükümü ile ilgili bir diğer husus da hakemin bir bilgiyi ifşa etmemesine bağlı olarak reddedilmesi halinde hakeme bir yaptırım uygulanıp uygulanmayacağı veya uygulanması gerekip gerekmediği olup, bu konuda henüz yerleşik bir kanaat bulunmamaktadır. ${ }^{80}$ Ancak hakemin kasti olarak bir bilgiyi ifşa etmemesinden kaynaklı reddi halinde taraflar bakımından tahkim masraflarının artması nedeniyle hakemin de belli ölçülerde sorumlu tutulması daha tercih edilebilir gözükmektedir.

\section{B. ICSID Tahkiminde Hakemin Reddi Süreci}

ICSID tahkiminde yapılacak hakemin reddi taleplerinin hangi zaman aralığında yapılacağ ICSID sisteminin diğer tahkim kurallarından ayrıştığ noktalardan biridir. Bu bakımdan ICSID Sözleşmesinde veya ICSID Tahkim Kurallarında hakemin reddi talebinin kaç gün içinde yapılması gerektiğine dair belirli bir gün sayısı ortaya konulmamıştır. Bunun yerine ICSID Tahkim Kuralları madde 9(1)'de hakemin reddi taleplerinin ret sebeplerinin öğrenilmesinden sonra 'derhal' yapılması gerektiği belirtilmiştir. ${ }^{81}$ ICSID Sözleşmesi madde 27(4)'e göre zamanında yapılmayan ret talebi, tarafın söz konusu hakkından vazgeçtiği anlamına gelmektedir. Ret talebinin yapılabileceği süre ile ilgili diğer tahkim kurallarında öngörüldüğü gibi $14-15$ veya 30 gün gibi net bir gün sayısının belirlenmemiş olması tartışmalara beraberinde getirmiştir. ${ }^{82}$

ICSID hakem kararları incelendiğinde tarafların hakemin reddi talebinin zamanında yapılmadığı üzerine sıklıkla itirazlarda bulundukları göze çarpmaktadır. Bu noktada örneğin Abaclat v Argentina tahkiminde 21 gün sonra yapılan hakemin reddi talebi karşı tarafın zamanında yapılmadığı itirazına rağmen zamanında yapılmış olarak kabul edilmiştir. ${ }^{83}$ Yahut bir başka tahkimde

79 CSID Case No ARB/10/5 Tidewater Inc v The Bolivarian Republic of Venezuela [2010] DECISION ON CLAIMANTS' PROPOSAL TO DISQUALIFY PROFESSOR BRIGITTE STERN, para 54.

80 Dina Prokic, 'The Annulment of Eiser v. Spain: A Call for Improvements to the System?' May 6, 2021, 4-5. <http://arbitrationblog.kluwerarbitration.com/2021/05/06/the-annulment-ofeiser-v-spain-a-call-for-improvements-to- the-system/ > erişim 30.05.2021

81 Scheurer ve diğerleri (n 56) 1200.

82 Sheppard (n 30) 156.

83 CSID Case No. ARB/07/5 ABACLAT AND OTHERS and ARGENTINE REPUBLIC [2014] DECISION ON THE PROPOSAL TO DISQUALIFY A MAJORITY OF THE TRIBUNAL, para 69. 
tam 7 ay sonra yapılan bir ret talebi zamanında yapılmış kabul edilmiştir. ${ }^{84} \mathrm{Aksi}$ yönde ise bir başka tahkimde 53 gün sonra yapılmış olan hakemin reddi talebi zamanında yapılmadığı gerekçesiyle reddedilmiştir. ${ }^{85}$ Söz konusu belirsizlikleri gidermek adına Tahkim Revizyon Çalışmaları kapsamında yayınlanan son versiyonda 21 gün şeklinde somut bir gün sayısının ortaya konulduğu görülmektedir. ${ }^{86}$ Ancak 21 gün yahut herhangi başka sabit bir gün belirlemenin ICSID sisteminin hakemin reddi talebinin yapılma süresi bakımından diğer tahkim kurallarından farklı olmasını sağlayan esnekliğini ortadan kaldıracağ 1 muhakkaktır. ICSID tahkiminde her zaman taraflardan birinin devlet olduğu düşünüldügünde ve devletler bakımından bürokratik meselelerin karar alma konusunda belli bir yavaşlığı beraberinde getirdiği dikkate alındığında ICSID tahkimi bakımından hakemin reddi taleplerini belli sürelerde yapılmasının zorunlu hale getirilmesi ICSID sisteminin hususiyetleriyle bağdaşmayacaktır.

Bunun yanında ret talepleri her halükârda hakem heyetinin oluşması ile tahkimin sona erdiğinin açıklandığı zaman aralığında yapılabilmektedir. ${ }^{87}$ $\mathrm{Bu}$ bakımdan hakem heyeti oluşmadan taraflardan birinin yapacağı hakemin reddi talebi ancak hakem heyeti oluştuktan sonra geçerlilik kazanabilecektir. ${ }^{88}$ Hakemlerin atanması ve hakem heyetinin resmi olarak oluşması arasında ciddi bir sürenin olduğu hesaba katıldığında hakemin reddi için hakem heyetinin oluşmasını beklemek tahkimin hızlılığı ilkesiyle çelişmektedir. ${ }^{89}$ $\mathrm{Bu}$ sebeple hakem seçimi sonrası hakemi reddetmek isteyen tarafin hakem heyetinin oluşmasını beklemeden de diğer tahkim kurallarında olduğu gibi ret talebinde bulunabilmesinin önünün açılması gerekmektedir. Ayrıca aynı tahkim yargılaması içinde farklı sebeplere dayanarak birden fazla kez hakemin reddi talebinde bulunmanın da önünde bir engel bulunmamaktadır. ${ }^{90}$ Hakemlerin tarafsız ve bağımsız olmadıklarının verdikleri karar sırasında veya sonrasında anlaşıldığ 1 takdirde ise tarafların artık hakemi reddetme şansları kalmadığ 1 için ancak ICSID Sözleşmesi 52(1) (a) veya (d) bentlerine dayanarak kararın iptalini veya öğretide önerilen bir diğer yol olan kararın düzeltilmesini talep edebilirler. ${ }^{91}$

ICSID tahkimi bakımından söz konusu ret talepleri tüm hakemlere karşı yapılabilir. ${ }^{92} \mathrm{Bu}$ bakımdan diğer tahkim kurallarının aksine ICSID tahkiminde

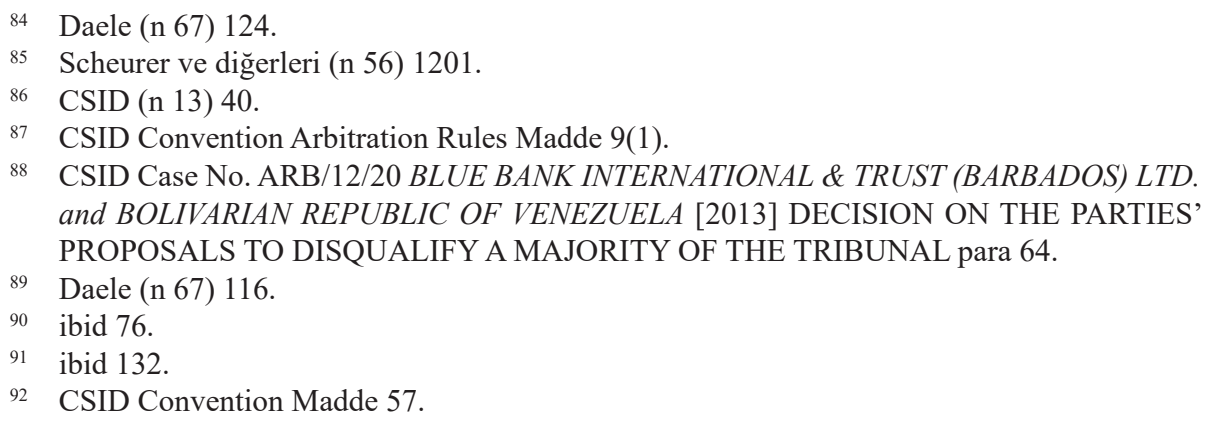


IIIIIIIIII-

hakemlerin reddi bakımından herhangi bir ayrım gözetilmemiştir. ${ }^{93}$ Ayrıca yine diğer tahkim kurallarından farklı olarak ICSID sisteminde taraflar hakemin reddi konusunda anlaşsalar dahi bu durum hakemin görevini sona erdirmemekte, son söz hakkı hakemin reddi kararını verecek mercide bulunmaktadır. ${ }^{94}$ ICSID tahkiminde tarafların hakemin reddi konusunda anlaşmalarına rağmen yine de hakemin reddine ilişkin kararın gerekmesi, tahkimde tarafların iradesinin ön planda olması mantığıyla uyuşmamaktadır. Hangi hakemlerin reddedilebileceği konusunda tartışmalı olan bir husus da hakem kararlarının iptali aşamasında görev alan ad hoc komite üyelerinin de reddedilebilmesi hususudur. ICSID Sözleşmesi madde 52(4)'te iptal aşamasında hangi maddelerin uygulama alanı bulabileceği ayrıntılı olarak düzenlenmiş, ancak hakemin reddine ilişkin madde bu kapsama dahil edilmemiştir. Buna dayanılarak iptal aşamasında görev alan ad hoc komite üyelerinin reddinin söz konusu olamayacağ ileri sürülmüştür. ${ }^{95}$ Ancak uygulamada birçok kez iptal aşamasında da tarafların hakemin reddi talebinde bulundukları görülmekte ve bunu ICSID Tahkim Kuralları madde 53 kapsamında tahkim kurallarının iptal aşamasında da uygulanacağ $ı$ hükmüne dayandırdıkları görülmektedir. ${ }^{96}$ Reddedilebilecek hakemler hususunda belirtilmesi gereken son husus da hakemin reddi talebine karar verecek diğer iki hakemin anlaşamaması durumunda hakemin reddine karar verecek olan ICSID İdari Konseyi Başkanı'nın da reddedilebileceğidir. Bu durumda bu ret talebini Daimî Hakemlik Mahkemesi Genel Sekreteri değerlendirecektir. ${ }^{97}$

Tahkimde görev alan bir hakemin reddi talep edildiğinde hakemin kendisi söz konusu ret talebi üzerine istifa edebilir. ${ }^{98}$ Özellikle ICSID tahkiminde birçok ret talebinin, karara bağlanmadan evvel hakemin kendi rızası ile istifas1 sonucu devam ettirilmediği görülmektedir. ${ }^{99}$ Ancak hakemin söz konusu ret talebine karşı çıkması halinde tahkim yargılaması otomatik olarak durdurularak ret talebi karar verecek mercie tevdi edilir. ${ }^{100}$ Bu noktada hakemin reddi talebi üzerine tahkimin otomatik olarak durması ve ortalama olarak ret taleplerinin 3-4 ay sürmesi, özellikle tahkimde cevap veren pozisyonunda yer alan devletleri zaman zaman ret prosedürünü davayı uzatmak veya cevap dilekçeleri için zaman kazanmak için kullanmaya sevk etmektedir. ${ }^{101} \mathrm{Bu}$ bakımdan ICSID tahkim sisteminde yer alan tahkimin otomatik durması yerine

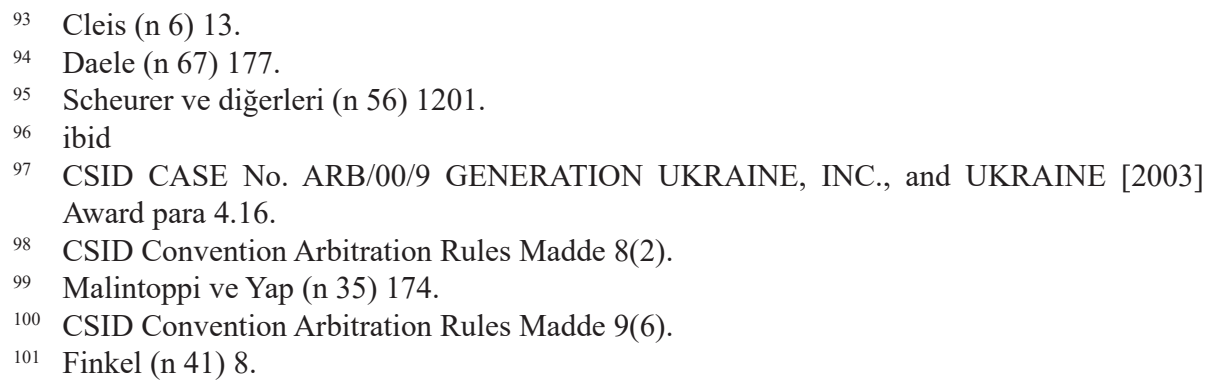


diğer tahkim sistemlerinde olduğu gibi hakem heyetinin takdirine bağlı durma kararının verilmesi, ${ }^{102}$ ICSID tahkiminde süreyi uzatma amaçlı yapılacak ret talebi başvurularını azaltmak bakımından etkili olabilecektir.

Reddi istenen hakemin ret talebine karşı çıkması halinde ret talepleri hakkında kimin karar vereceği konusu ICSID tahkim sistemini diğer tahkim sistemlerinden ayıran bir diğer özelliktir. Bu bakımdan ICSID Tahkim Kuralları madde 9(4)'e göre hakemin reddi talebini, reddedilmeyen diğer hakimler; eğer birden fazla hakem birlikte reddedilmişse veya hakemler ret konusunda anlaşamazlarsa bu durumda ICSID İdari Konseyi Başkanı inceleyecektir. Hakemin reddi talebini değerlendirmeyi diğer hakemlere birakan bu sistemde karar verici pozisyondaki hakemler bir başka tahkimde kendilerinin de reddedilme ihtimalini düşünerek genelde ret taleplerini kabul etmeye sicak bakmamaktadırlar. ${ }^{103}$

ICSID tahkiminde hakemin reddi standartlarında son yıllarda benimsenen yumuşamaya rağmen hala ICSID hakemin reddi oranlarının diğer tahkim sistemlerine nazaran çok daha düşük seviyelerde kalması, ${ }^{104}$ sorunun hakemin bağımsızlığg ve tarafsızlığına ilişkin standartlarda değil, tamamen ICSID’e özgü söz konusu ret karar verme prosedürü ile ilgili olduğunu göstermektedir. $\mathrm{Bu}$ bakımdan ICSID tahkiminde hakemlerin bağımsızlığı ve tarafsızlığını garanti edecek hakemin reddi mekanizmasının daha işlevsel hale getirilebilmesi için, hakemin reddi taleplerine reddedilmemiş hakemlerin bakması uygulamasından vazgeçilmelidir. ${ }^{105}$ Hakemin reddi konusunda karar verecek hakemlerin üzerindeki baskıyı kaldıracak, daha objektif kararlar çıkmasını temin edecek şekilde diğer tahkim sistemlerinde de olduğu gibi ICSID İdari Konseyi gibi bir organın ret talepleri konusunda karar vermesi daha sağlıklı bir çözüm olarak gözükmektedir. Ancak bu değişiklik ICSID Sözleşmesi'nin değiştirilmesini gerektirdiği ve bu durumun pratikte pek de mümkün olmadığı düşünüldüğünde ${ }^{106}$ yapılabilecek en gerçekçi çözümün ICSID tahkiminde görev alan hakemlerin kendi aralarında profesyonel nezaket çerçevesinde anlaşarak hakemin reddi taleplerine bakmayacaklarını ve bunu doğrudan ICSID İdari Konsey Başkanı'na bırakacaklarını kararlaştırmalarıdır. ${ }^{107} \mathrm{Bu}$ anlaşma sistemin eksikliğini tamamen giderecek nitelikte olmasa da reddedilmeyen hakemlerin karar vermesi yerine Konsey Başkanı'nın karar vermesi daha objektif ve istikrarlı kararları beraberinde getirecektir.

102 Daele (n 67) 110-111.

103 Chiara Giorgetti, 'Challenges of International Investment Arbitrators: How Does It Work, and Does It Work?' (2013) 7(2) World Arbitration \& Mediation Review 303, 317.

104 Finkel (n 41) 8.

105 Bottini (n 40) 365.

106 Giorgetti (n 103) 317.

107 Marc Lalonde, 'Chapter 46: Quo Vadis Disqualification?', in Meg Kinnear ve diğerleri. (eds), Building International Investment Law: The First 50 Years of ICSID, (Kluwer Law International 2015), 652. 
IIIIIIIIIII-

Ret süreci bakımından belirtilmesi gereken son husus ICSID tahkiminin kapalı bir sistem oluşunun bir yansıması olarak iptal sürecinde olduğu gibi ret talepleri sürecinde de tahkimin görüldüğü yer mahkemelerinde veya ulusal mahkemelerde hakem heyetinin veya Konsey Başkanı'nın hakemin reddi talebine ilişkin aldığ karara karşı itiraz edilebilmesinin diğer tahkim kurallarında olduğunun aksine mümkün olmamasıdır. ${ }^{108}$

\section{ICSID Tahkiminde Ret Sebebi Olarak En Çok İleri Sürülen Durumlar}

\section{Hakemin veya Hakemin Avukatlık Bürosunun Tarafla, Taraf Avukatıyla veya Diğer Kişilerle Olan İlişkisi}

ICSID tahkiminde ret sebebi olarak en sk ileri sürülen sebeplerden biri hakemin, hakemin yakın akrabalarının veya hakemin avukatlık bürosunun tarafla, taraf avukatıyla yahut uzman tanıkla olan ilişkileridir. Ret taleplerinin kabul edilip edilmemesinde, ret talebini değerlendiren heyetin veya Başkanın ilgili madde metnindeki 'açık bir şekilde' ibaresini nasıl yorumladığının önemli olmasının yanında hakemin söz konusu kişilerle olan ilişkisinin yoğunluğu da ret talebinin kabul edilip edilmemesinde önemli rol oynamıştır. Bu bakımdan Getme $v$ Guinea tahkiminde hakemin kardeşinin taraflardan birinin başka bir tahkim davasında hakem olarak atanması ret sebebi olarak ileri sürülmüş ancak kabul edilmemiştir. ${ }^{109}$ Yine benzer şekilde ConocoPhillips $v$ Venezuela tahkiminde hakemin çalıştığ 1 avukatlık bürosunun taraflardan biri ile olan ilişkisi ret talebine konu olmuş ama yine kabul görmemiştir. ${ }^{110}$ Hakem-avukat ilişkisi bakımından ise Alpha v Ukraine tahkiminde hakemin taraflardan birinin avukatıla 20 y1l önce aynı okula gitmesi, ${ }^{111}$ Nations Energy $v$ Panama davasında hakemin taraf avukatlıyla geçmişte 7 yıl beraber çalışmaları ret sebebi olarak ileri sürülmüş, ama kabul görmemiştir. ${ }^{112}$ Hakem-uzman tanık ilişkisi bakımından ise Eiser v Spain tahkiminde hakemin uzman tanıklardan biri ile olan ilişkisi iptal sebebi olarak ileri sürülmüş ve bu sefer kararın iptaline sebep olmuştur. ${ }^{113}$

108 Fry ve Stampalija (n 33) 209.

109 ICSID Case No. ARB 11/29 GETMA INTERNATIONAL and others $v$ Republic of Guinea [2012] Decision on the Proposal for Disqualification of Arbitrator Bernardo M. Cremades, para 24.

110 ICSID Case No. ARB 07/30 ConocoPhilips and others v Bolivarian Republic of Venezuela [2012] Decision on the Proposal for Disqualify L.Yves Forther , para 6.

111 ICSID Case No. ARB/07/16 ALPHA PROJEKTHOLDING GMBH and UKRAINE [2010] Decision on Respondent's Proposal to Disqualify Arbitrator Dr. Yoram Turbowicz para 12.

112 ICSID Case No. ARB/06/19 Nations Energy Corporation v Republic of Panama [2011] Decision on the Proposal to Disqualify Dr. Stanimir A. Alexandrov para 22.

113 ICSID Case No. ARB/13/36 EISER INFRASTRUCTURE LIMITED AND ENERGÍA SOLAR LUXEMBOURG S.À R.L. Claimants and KINGDOM OF SPAIN [2020] DECISION ON THE KINGDOM OF SPAIN'S APPLICATION FOR ANNULMENT para 52. 


\section{Hakemin Birden Fazla Kez Atanması}

Tahkim taraflarınca en s1k şekilde ileri sürülen ret sebeplerinden biri de ayn hakemin birden fazla kere atanması durumudur. Bu durum hakemin aynı tarafça, aynı avukatlık bürosunca veya aynı tarafa karşı atanması şeklinde tezahür edebilmektedir. Örnek olarak OPIC v. Venezuela tahkiminde hakemin Venezuella tarafindan birden fazla kez atanmas1, ${ }^{114}$ Burlington Resources $v$. Ecuador 'da hakemin Freshfields avukatlik bürosu tarafindan birden fazla kez atanmas1, ${ }^{115}$ Raiffeisen Bank v. Croatia tahkiminde hakemin toplam 38 hakemlik görevinin $35^{\prime}$ inde talep eden taraf (claimants) tarafindan hakem olarak atanmas1, ${ }^{116}$ Ayat Nizar Raja Sumrain v. Kuwait tahkiminde ise tam tersi olarak hakemin ağırlıklı olarak devletler tarafından atanıyor olması ret sebebi olarak ileri sürülmüştür. ${ }^{117}$ Görüleceği üzere ICSID tahkiminde hakemlerin birden fazla kez atanması sık karş1laşılan bir durum olup 2016-2020 arası atanan hakemlerin yaklaşık yarısının birden fazla kez atandığı tespit edilmiştir. ${ }^{118}$ Hakemin birden fazla kez atanması bu bakımdan dikkatle değerlendirilmesi gereken bir husustur. Bir tarafta birden fazla kez atanan hakemin kendisini atayan tarafa ekonomik veya duygusal bir bağımlılık geliştirme endişesi, ama bir taraftan da tarafların kendi tezlerini en iyi anlatabilecekleri hakemleri birden fazla kez seçebilme özgürlükleri aynı anda dikkate alınmalıdır. ${ }^{119}$

ICSID tahkimi kararlarına bakıldığında ticari tahkimin aksine hakemin birden fazla kez atanmasına dayalı ret taleplerinin genellikle kabul edilmediği görülmektedir. ${ }^{120} \mathrm{Bu}$ bakımdan 2010-2020 arasında 10 defa hakemin birden fazla kez atanmasına dayalı ret talebi yapılmış olması rağmen bu taleplerin hiçbiri kabul edilmemiştir. ${ }^{121}$ Verilen kararlar incelendiğinde birden fazla defa atanmanın hakemin bağımsızlığını ve tarafsızlığını tek başına ortadan

114 ICSID Case No. ARB/10/14 OPIC Karimum Corporation v. The Bolivarian Republic of Venezuela [2011] DECISION ON THE PROPOSAL TO DISQUALIFY PROFESSOR PHILIPPE SANDS para 11.

115 CSID Case No. ARB/08/5 BURLINGTON RESOURCES, INC. and REPUBLIC OF ECUADOR [2013] DECISION ON THE PROPOSAL FOR DISQUALIFICATION OF PROFESSOR FRANCISCO ORREGO VICUÑA, para 20.

116 ICSID Case No. ARB/17/34 RAIFFEISEN BANK INTERNATIONAL AG and REPUBLIC OF CROATIA [2018] DECISION ON THE PROPOSAL TO DISQUALIFY STANIMIR ALEXANDROV, para 16.

117 ICSID Case No. ARB/19/20 AYAT NIZAR RAJA SUMRAIN and STATE OF KUWAIT [2020] DECISION ON THE CLAIMANTS' PROPOSAL TO DISQUALIFY PROF. ZACHARY DOUGLAS AND MR. V. V. VEEDER para 31

118 ICSID, 'CODE OF CONDUCT - BACKGROUND PAPERS: REPEAT APPOINTMENTS' (2021), $9<$ https://icsid.worldbank.org/sites/default/files/Background_Papers_Repeat Appointments_final_25.2.2021.pdf > erişim 30.05.2021

119 ibid 1-2.

120 Cleis (n 6) 154.

121 CSID (n 118) 2. 
IIIIIIIIII!

kaldırmayacağı, bunların ortadan kalkabilmesi için hakemin söz konusu tekrar eden atamalar neticesinde tarafa ekonomik olarak bağımlı hale gelmiş olmasının ortaya konulması gerektiği belirtilmektedir. ${ }^{122} \mathrm{Bu}$ bağlamda yüzlerce hakemlik dosyası olan bir hakemin bir tarafça sadece iki veya üç sefer atanmış olması, o hakemi söz konusu tarafa ekonomik olarak bağımlı kılmayacak ve bu sebeple bağımsızlığ 1 etkilemeyecektir. ${ }^{123}$

IBA Kılavuzuna göre hakemin son üç yıl içerisinde aynı taraf tarafindan 2 veya daha fazla kez, aynı avukatlık bürosu tarafindan ise 3 veya daha fazla kez atanması ifşa edilmesi gereken bir durum olup turuncu liste altında sınıflandırılan bir durum olarak görülmektedir. ${ }^{24}$ Ancak ICSID sisteminde hakeme böyle bir ifşa yükümlülüğü açıç̧a getirilmemektedir. Bunun arkasındaki sebepse ICSID tahkiminin halka açık oluşu sebebiyle hakemlerin hangi tarafça kaç kez atandıklarının bilinmesidir. Ticari tahkimde ise bir hakemin hangi davada hangi taraf adına kaç kere atandığının bilinmemesi ifşa yükümlülüğünü gerekli hale getirmektedir. Esasında hakemin birden fazla kez atanmasına ilişkin duyulan endişelerin ve hatta bu tarz durumların IBA Kılavuzuna dahi konu edilmelerinin altında yatan asıl sebep ticari tahkimde hakem havuzunun çok geniş olmasına rağmen aynı hakemin tekrar tekrar atanmasına karşı duyulan endişedir. Ancak yatırım tahkimindeki hakem havuzunun çok sınırlı oluşu karşısında aynı hakemlerin tekrar tekrar atanıyor oluşunun ICSID bağlamında ciddi bir ret sebebi olarak kabul edilmeyişi yatırım tahkimindeki bu özelliğin bir sonucudur. Bu durum aynı zamanda IBA Kılavuzunun yatırım tahkimine ve daha özelde ICSID sistemine her zaman doğrudan uygulanmasının çok sağlıklı bir yöntem olmayacağını da ortaya koymaktadır.

\section{Hakemin Aynı Anda Başka Bir Tahkimde Görev Yapması}

ICSID tahkiminde hakemin bağımsızlığını ve tarafsızlığını gündeme getiren bir başka önemli ret sebebi de hakemin aynı anda taraflardan birinin olduğu veya benzer konuları içeren başka bir tahkim yargılamasında görev almasıdır. ${ }^{125} \mathrm{Bu}$ bakımdan KS Invest $v$ Spain tahkim davasında hakemin benzer konuları tartışan başka bir tahkim yargılamasında avukat olarak görev alması ret sebebi olarak ileri sürülmüş, ancak söz konusu iki tahkim yargılaması arasında yeterince bağlantı bulunamadığ 1 için ret sebebi kabul edilmemiştir. ${ }^{26}$ Yine benzer şekilde Bluebank v Venezuela tahkiminde hakemin çalıştığı avukatlık

122 ibid 6.

123 Daele (n 67) 363.

124 Guidelines (n 46) part 23.1 .3 ve 3.1.4.

125 ICSID, 'CODE OF CONDUCT - BACKGROUND PAPERS: Double Hatting' (2021), 1 $<$ https://icsid.worldbank.org/sites/default/files/Background_Papers_Double-Hatting _ (final)_2021.02.25.pdf $>$ erişim 30.05.2021

126 ICSID Case No. ARB/15/25 KS INVEST GMBH and KINGDOM OF SPAIN [2020] DECISION ON THE PROPOSAL TO DISQUALIFY PROF. KAJ HOBÉR para 25. 
bürosunun taraflardan birine karşı yürütülen başka bir tahkim davasında avukatlık hizmeti vermesi, hakemin söz konusu davadan elde edilecek gelirde çıkarının olması gerekçe gösterilerek reddi istenmiş ve bu ret sebebi kabul edilmiştir. ${ }^{127}$ Bununla birlikte Caratube v Kazakhstan tahkiminde hakemin başka bir tahkimde taraflardan biri tarafından atanmış hakem olması ret sebebi olarak ileri sürülmüş, söz konusu iki tahkim davasının benzer nitelikte olması nedeniyle ret talebi kabul edilmiştir. ${ }^{28}$

$\mathrm{Bu}$ sebeple ilgili kararlar topluca incelendiğinde hakemin aynı anda başka bir tahkimde aldığı görev dolayısıyla bağımsızlığının ve tarafsızlığının şüpheye düştügüunden bahisle reddedilebilmesi için görev aldığı iki tahkimin çok ciddi ölçüde birbiriyle örtüşmesinin arandığı görülmektedir. Aksi halde bu sebebe bağl1 ret talepleri kabul edilmemektedir.

Hakemin aynı anda başka bir tahkimdeki görevi sebebiyle reddine ilişkin yapılması gereken düzenlemeler konusu da tartışmalıdır. Bir tarafta hakemlerin aynı birden fazla görev almasının Spor Tahkim Mahkemesi'nde (CAS) olduğu gibi tamamen yasaklanmas1 ${ }^{129}$ gerektiğini savunanlar olduğu gibi, buna karş1 çıarak tamamen yasaklamak yerine sadece buna ilişkin ifşa yükümlülüklerin detaylandırılması gerektiğini savunan görüşler de vardır. ${ }^{130} \mathrm{Bu}$ görüşe göre hakemlerin bir tahkim davasında hakemlik yaptıkları esnada başka bir tahkimde görev yapmalarının engellenmesi, hakemin sadece o tahkim ile ekonomik olarak geçimini sürdürebilecek durumda olabilmesini gerektirmekte olup; bunu sağlayabilecek hakem sayısı çok kısıtlı olduğu için söz konusu yasaklama uzun vadede hakem havuzunu ciddi bir biçimde daraltacaktır. ${ }^{131}$ Her ne kadar birçok devlet de söz konusu yasaklamaya karşı çıksa da ${ }^{132}$ Taslak Davranış Kurallarında hakemlerin taraflardan en az birini içeren veya benzer konularda

127 ICSID Case No. ARB/12/20 BLUE BANK INTERNATIONAL \& TRUST (BARBADOS) LTD. and BOLIVARIAN REPUBLIC OF VENEZUELA [2013] DECISION ON THE PARTIES' PROPOSALS TO DISQUALIFY A MAJORITY OF THE TRIBUNAL para 22.

128 ICSID Case No. ARB/13/13 Caratube International Oil Company LLP v. Republic of Kazakhstan [2014] DECISION ON THE PROPOSAL FOR DISQUALIFICATION OF Mr. Bruno Boesch para 90.

129 CSID (n 125) 9.

130 Hwang ve Lim (n 5) 32.

131 Vanina Sucharitkul, 'ICSID and UNCITRAL Draft Code of Conduct: Potential Ban on Multiple Roles Could Negatively Impact Gender and Regional Diversity, as well as Generational Renewal' (2020), 4- 5<http://arbitrationblog.kluwerarbitration. com/2020/06/20/icsid-and-uncitral draft-code-of-conduct-potential-ban-on- multiple-rolescould-negatively-impact gender-andregional-diversity-as-well-as-generational-renewal/> erişim 30.05.2021.

132 CSID ve UNCITRAL, 'DRAFT CODE OF CONDUCT Comments by State/Commenter' (2021), 63-64 <https://icsid.worldbank.org/sites/default/files/Code $\% 20$ of $\% 20$ Conduct $\% 20$ -\%20Comments\%20by\%20State- Commenter\%20-\%20Updated\%2001.14.21.pdf> erişim 30.05 .2021 
IIIIIIIIII!

olan tahkim davalarında ya da bunlar aranmaksızın tüm diğer tahkimlerde aynı birden fazla görev almalarını tamamen yasaklayacak nitelikte düzenlemeler olduğu görülmektedir. ${ }^{133}$ Ancak bu düzenlemelerin devletlerin de dile getirdiği gibi zaten sınırlı olan hakem havuzunu daraltacağ 1 açı olup, bunun yerine ifşa yükümlerinin arttırılması daha uygun bir seçenek olarak görünmektedir. ${ }^{134}$

\section{Hakemin Tahkim Sürecindeki Tutumu}

Hakemin tarafla olan ilişkileri bağlamında ortaya çıkan bağımsızlık sorunlarının yanında tahkim esnasında taraflara karşı olan muamelesi neticesinde de tarafsızlık ile ilgili konular gündeme gelebilmektedir. Bu durum Quiborax v. Bolivia ${ }^{135}$ veya Landesbank Baden v Spain tahkiminde olduğu gibi hakem heyetinin tahkim sırasında vermiş olduğu ara karar neticesinde ortaya çıkabileceği gibi, ${ }^{136}$ Eugene Kazmin v Latvia'da olduğu gibi hakem heyetinin vermiş olduğu ara kararda kullanıldığı iddia edilen alaycı ve üsttenci dil neticesinde de ortaya çıkabilmektedir. ${ }^{137}$ Bununla birlikte Burlington $v$ Ecuador tahkiminde olduğu gibi hakemin telekonferans sirasında taraflardan birine karşı daha ayrıcalıklı sorular sorması iddiasıyla da ortaya çıkabiliir, ${ }^{138}$ ki bu tahkimde ret talebini inceleyen Konsey Başkanı hakemin telekonferans sırasında sorduğu soruların reddini gerektirmediğini ama tarafin ret talebine karşı vermiş olduğu yazılı beyanat ile tarafsızlığının şüpheye düştügünü belirterek ret talebini kabul etmiştir. ${ }^{139}$

\section{Hakemin Daha Önce Benzer Konuda veya Taraflardan Birinin Aleyhine Karar Vermesi}

Hakemin daha önce taraflardan birinin aleyhine veya benzer konuda başka bir tahkim yargilamasında karar vermesi de çoğu zaman ret sebebi olarak ileri sürülmektedir. Bu bakımdan örneğin VM Solar v Spain tahkiminde İspanya, hakemin daha önce benzer nitelikte kendisine karşı başlatılan 3 tahkim yargılamasında yatırımcılar tarafından atanmış olmasını ret sebebi olarak ileri

133 Code of Conduct for Adjudicators in Investor-State Dispute Settlement (version two), Madde 4.

134 Sucharitkul (n 131) 7.

135 Daele (n 67) 411.

136 CSID Case No. ARB/15/45 LANDESBANK BADEN-WÜRTTEMBERG ET AL. and KINGDOM OF SPAIN [2020] DECISION ON THE SECOND PROPOSAL TO DISQUALIFY ALL MEMBERS OF THE TRIBUNAL para 42.

137 CSID Case No. ARB/17/5 EUGENE KAZMIN and REPUBLIC OF LATVIA [2020] DECISION ON THE PROPOSAL TO DISQUALIFY ALL MEMBERS OF THE TRIBUNAL para 32.

138 CSID Case No. ARB/08/5 BURLINGTON RESOURCES, INC. and REPUBLIC OF ECUADOR [2013] DECISION ON THE PROPOSAL FOR DISQUALIFICATION OF PROFESSOR FRANCISCO ORREGO VICUÑA, para 30.

139 ibid para 80. 
sürmüştür. ${ }^{100}$ Bir başka tahkim yargılamasında hakemin taraflardan biri aleyhine daha önce 3 başka tahkim yargılamasında karar vermesi ve hatta bu 3 kararın da daha sonra iptal edilmiş olması ret sebebi olarak ileri sürülmüş ancak bu söz konusu tahkim yargılamalarının farklı nitelikler taşıması nedeniyle ret talebi kabul edilmemiştir. ${ }^{141}$ Bluebank $v$ Venezuela tahkiminde bu sefer hakemin sistematik olarak devletler lehine karar vermiş olması ret sebebi yapılmış, ancak bu konuda bir karar verilmeden hakem istifa etmiştir. ${ }^{142}$

Genel olarak ICSID tahkiminde hakemin daha önce taraf aleyhine karar vermesine veya benzer konuda karar vermiş olmasına dayalı ret sebepleri incelendiğinde tek başına taraf aleyhine karar vermiş olmanın veya benzer konuda karar vermiş olmanın her bir tahkim yargılamasının birbirinden farklı nitelikler taşıması sebebiyle, hakemin vermiş olduğu karar hatalı olmuş olsa dahi, ${ }^{143}$ hakemin bağımsızlığını şüpheli hale getirmediği kabul edilmekte ve bu sebeple buna bağlı ret talepleri genellikle kabul görmemektedir. ${ }^{144}$ Kald 1 ki benzer konuda karar vermiş olmasına dayalı olarak hakemlerin reddi kabul edilecek olsaydı, yatırım tahkiminde uyuşmazlık konusu olan konuların çok sınırlı olduğu dikkate alındığında tarafsızlığı şüpheye düşmeyecek hakem bulmak imkânsız hale gelirdi.

\section{Hakemin Uyuşmazlık Konusu Hakkında Akademik Yayın Yapmış Olması}

ICSID bakımından ret sebebi olarak en çok ileri sürülen ve bu konuda tartışmaların en yoğun yaşandığı konulardan biri de hakemlerin görevlendirildikleri uyuşmazlık hakkında daha önceden akademik olarak yayın yapmış olmalarıdır. Örneğin Saipem v. Bangladesh tahkiminde hakemin uyuşmazlığın esasını oluşturan konular hakkında daha önceden akademik yayınlarda bulunmuş olması ret sebebi olarak ileri sürülmüş ancak diğer hakemler, söz konusu talebi hakemin somut uyuşmazlığa herhangi bir atıf yapmadan genel hukuki hatlarıla akademik olarak incelemesi sebebiyle

140 CSID Case No. ARB/19/30 VM SOLAR JEREZ GMBH and KINGDOM OF SPAIN [2020] DECISION ON THE PROPOSAL TO DISQUALIFY PROF. DR. GUIDO SANTIAGO TAWIL para 39.

141 CSID Case No. No. ARB/12/38 Repsol SA v Republic of Argentina [2013] Decision on the Proposal for Disqualification of Arbitrators Francisco Orrego Vicuna and Claus von Wobeser para 25

142 CSID Case No. ARB/12/20 BLUE BANK INTERNATIONAL \& TRUST (BARBADOS) LTD. and BOLIVARIAN REPUBLIC OF VENEZUELA [2013] DECISION ON THE PARTIES' PROPOSALS TO DISQUALIFY A MAJORITY OF THE TRIBUNAL para 45.

143 Cleis (n 6) 56.

144 CSID, 'CODE OF CONDUCT - BACKGROUND PAPERS ISSUE CONFLICT' (2021), 7-11 $<$ https://icsid.worldbank.org/sites/default/files/Background_Papers_Issue_Conflict_ Final_2.26.2021.pdf> erişim 30.05.2021 
IIIIIIIIIII-

ret talebini kabul etmemişlerdir. ${ }^{145}$ Yine Urbaser $v$ Argentina tahkiminde taraflardan biri hakemin 'en çok gözetilen ulus kaydı' konusunda görüşlerini yazmış olduğu bir akademik yayında beyan etmiş olduğunu ve bu konunun somut uyuşmazlık bakımından da çok önemli olduğunu, hakemin söz konusu görüşünü geri dönemeyecek derecede şiddetli bir biçimde savunduğunu gerekçe göstererek reddini talep etmişse de söz konusu talep kabul edilmemiştir. ${ }^{146}$

Genel olarak bu ret sebebine ilişkin diğer tahkim yargılamalarında kabul edilmiş ret kararları olsa da ${ }^{147}$ ICSID tahkiminde, hakemin uyuşmazlık konusu hakkında daha önce akademik görüşünü ifade etmesine dayalı kabul edilen bir ret talebi bulunmamaktadır. Bu bakımdan ICSID tahkiminde verilen kararlarda her bir tahkimin kendine has nitelikler taşıdığı, hakemin somut uyuşmazlığa doğrudan referans vermemek kaydıyla beyan ettiği görüşün tek başına tarafsızlığını etkilemeyeceği; ${ }^{148}$ kaldı ki bir hakemin akademik olarak beyan ettiği görüşünü daha sonra değiştirebilmesinin de pekâlâ mümkün olduğu kabul edilmektedir. ${ }^{149}$ Ayrıca hakemlerin akademik görüşlerinden ötürü reddinin kabul edilmesinin hakemleri akademik yayın yapmaktan uzaklaştıracağı ve akademik gelişimi yavaşlatacağ $\mathrm{kabul}$ edilmektedir. ${ }^{150}$

ICSID tahkiminde benimsenen bu görüş, maalesef, pratikle ve gerçeklikle pek uyumlu değildir. Zira belli bir pozisyona ve akademik olgunluğa gelmiş ve yıllarca bir görüşü savunmuş olan bir hakemin zaten sınırlı sayıda tartışma konusunun olduğu bir ICSID tahkiminde görüşünü değiştirebileceğini yahut somut uyuşmazlığa daha önce yayımladığı akademik görüşlerin dışında bakabileceğini beklemek gerçekçi gözükmemektedir. ${ }^{151} \mathrm{Bu}$ bağlamda sevindirici bir gelişme olarak Taslak Davranış Kurallarının ilk versiyonunda hakemlere yayınlamış oldukları tüm akademik çalışmaları ifşa yükümü getirilmekteyken, ${ }^{152}$ daha sonraki versiyonda bu ifşa yükümlülüğünden şaşırtıcı bir biçimde vazgeçilmiştir. İlk versiyondaki ifşa yükümlülügünün

145 ibid 15.

146 CSID Case No. ARB/07/26 URB ASER S.A.and Argentine Republic [2010] Decision on Proposal to Disqualify Professor Campbell MacLachlan para 20-21 ve para 41.

147 PCA CASE No 2013-09 CC/DEVAS (MAURITIUS) LTD and THE REPUBLIC OF INDIA [2013] Decision on the Respondent's Challenge to the Hon. Marc Lalonde as Presiding Arbitrator and Prof. Francisco Orrego Vicuna as Co- Arbitrator para 64.

148 CSID (n 144) 16.

149 Doak Bishop ve Lucy Reed, 'Practical Guidelines for Interviewing, Selecting and Challenging Party-Appointed Arbitrators in International Commercial Arbitration (1998) 14(4) ARBITRATION INTERNATIONAL 395, 412.

${ }_{150} \operatorname{CSID}(\mathrm{n} 144) 16$.

151 Lalonde (n 107) 659.

152 Code of Conduct for Adjudicators in Investor-State Dispute Settlement (version one) Madde 5(2)c <https://icsid.worldbank.org/sites/default/files/amendments/Draft_Code_Conduct_ Adjudicators_ISDS.pdf $>$ erişim 30.05.2021 
tekrar getirilmesi hakemlerin tarafsızlığını temin etme ve ICSID tahkiminin meşruiyetini geliştirmek bakımından daha gerçekçi bir yol olarak ortada durmaktadır.

\section{SONUÇ}

Tahkimde görev alan hakemlerin bağımsızlığını ve tarafsızlığını garanti etmek için hakemlere yönelik getirilen ifşa yükümü ve hakemin reddi prosedürlerinin son derece önemli olduğu muhakkaktır. Bu alanda ön plana çıkan tahkim kurumlarının tahkim kuralları, ad hoc tahkimde uygulama alanı bulan UNCITRAL Tahkim Kuralları ve diğer bağlayıcı olmayan kılavuzlar ile karşılaştırıldığında ICSID tahkiminin, hakemin bağımsızlığı, tarafsızlığı, ifşa yükümü veya ret prosedürü gibi konularda farklı düzenlemeler içerdiği görülmektedir. ICSID sistemindeki bu farkl1lıklar temelde hakemlerin ifşa yükümlerinin çok geniş olduğu ama buna zıt olarak hakemin reddi standardının çok yüksek olduğu ve bunlara bağlı olarak ret talep oranının çok fazla ancak ret talebi kabul oranının çok düşük olduğu bir sonuç meydana getirmiştir. Ortaya çıkan bu durum ICSID tahkimindeki hakemin reddi mekanizmasının işlevselliğinin sorgulanmasına yol açmıştır. Buradan hareketle yapılan bu çalışmada ICSID tahkiminde hakemin reddi konusu diğer tahkim kurallarıyla karşılaştırmalı olarak ele alınmış, ICSID sistemindeki eksiklikler ortaya konulmaya ve çözüm önerileri getirilmeye çalışılmıştır.

ICSID tahkiminde hakemin reddi konusunda en mühim hususlardan birinin ICSID Sözleşme metninde hakemin bağımsızlığına ilişkin aranan eksikliğin 'açık bir şekilde' (manifest) olması gerektiği düzenlemesidir. Bu ibare nedeniyle ICSID tahkiminde hakem heyetleri ret talebini kabul etmek için daha ciddi durumlar aramışlar ve bu sebeple çoğu ret talebini geri çevirmişlerdir. İlk yıllardan beri zaman zaman başka yönde kararlar olsa da bu yaklaşım benimsenmiş ve diğer tahkim kurallarında benimsendiği şekilde sadece makul şüphenin yeterli olması kabul edilmemiştir. Ancak 2013 yılında ilk defa diğer tahkim kurallarında kabul edildiği şekilde makul şüphenin yeterli olduğu kabul edilmeye başlanmış ve bu yaklaşım istikrarlı bir biçimde günümüze değin devam ettirilmiştir. Böylece ICSID tahkiminde hakemin reddi mekanizmasını işlevsiz kılan bir engel ortadan kalkmış ve ICSID kuralları diğer tahkim normlarıyla uyumlu hale gelmiştir. Bu durum çok olumlu bir gelişme olmakla beraber, ICSID tahkimi kararlarının gözden geçirilme imkanlarının daha da az oluşu ve ICSID tahkimi uyuşmazlıklarında konu edilen ekonomik değerin çok daha yüksek oluşu gibi sebepler dikkate alındığında, ICSID bakımından hakemlerin bağımsızlığını ve tarafsızlığını temin etmenin önemi daha fazla ön plana çıkmakta ve bu sebeple zaman içerisinde ICSID bakımından hakemin reddi standartlarının daha da kolaylaştırılması beklenmektedir.

ICSID tahkiminde hakemin reddine ilişkin standartların kolaylaştırılması ve sadece haklı şüphenin yeterli görülmesi tüm sorunları ortadan kaldırabilecek 
IIIIIIIIII!

nitelikte çözüm değildir. Zira ICSID tahkiminde hakemin reddi mekanizmasını işlevsiz hale getiren asıl sebeplerden biri hakemin reddi talebine reddedilmeyen diğer hakemlerin karar verecek olmasıdır. Bu düzenleme hakemleri birbirlerini reddetmekten imtina etmeye ve sonuçta ICSID tahkiminde hakemin reddini pratikte imkânsız hale getirmektedir. Ret talebini karara bağlamak yetkisini diğer hakemlerden almanın bir sözleşme değişikliği gerektirmesi ve bunun da yakın süreçte pek olası gözükmemesi karşısında hakemlerin profesyonel nezaket çerçevesinde aralarında anlaşmayı teamül haline getirerek ret talepleri konusunda karar vermeyi ICSID İdari Konsey Başkanına bırakmaları daha gerçekçi bir çözüm olarak görünmektedir.

ICSID tahkiminde hakemin reddi konusunda diğer tahkim kurallarından farklı nitelikte olup da korunması gereken özellikler de bulunmaktadır. Bunların başında ICSID tahkiminde hakemin reddinin yapılabilmesi için diğer tahkimlerde olduğunun aksine sabit bir gün belirlenmeyişidir. Zira ICSID tahkiminde bir tarafın her zaman devlet olduğu ve devletler bakımından bürokratik işlemlerin belli ölçüde yavaşlamaya sebep olduğu dikkate alındığında belli bir gün sayısı belirlenmeyişi esasında ICSID tahkiminde hakemin reddi talebinde bulunacak tarafa esneklik sağlamaktadır. Bu bakımdan ICSID Tahkim Kuralları Revizyon Çalışmaları kapsamında önerilen 21 gün düzenlemesi ICSID sistemindeki esnekliği ortadan kaldırabilecek nitelikte bir düzenlemedir.

ICSID tahkiminde hakemin reddine ilişkin verilen kararlar incelendiğinde ise göze çarpan ilk hususlardan biri IBA Kılavuzunun ICSID tahkimindeki hakemin reddi sürecine doğrudan uygulanmasının yarattı̆̆ problemdir. Zira IBA Kılavuzu birçok noktada ICSID tahkiminin hususiyetleriyle örtüşmemekte ve bu durum da hakemin reddi süreçlerinde açıkça ortaya çıkmaktadır. Bu bakımdan hakemin tekrar atanması konusunda IBA Kılavuzunda gösterilen şüphenin ve bu durum gerekçe gösterilerek tarafların tekrar atanma konusunu ICSID hakemin reddi süreçlerinde sik s1k ileri sürmelerine rağmen bu taleplerin devamlı olarak reddediliyor olması bu konunun ICSID bakımından o derece ciddi bir konu olmadığını göstermektedir. $\mathrm{Bu}$ durumun tam aksine olacak şekilde IBA Kılavuzunda ciddi bir durum olarak görülmeyen hakemin uyuşmazlık konusu hakkında akademik yayın yapması meselesi ICSID tahkimi bakımından ciddi şüpheler yaratabilecek bir konu olup, IBA Kılavuzunun bu konuda doğrudan ICSID tahkimine uygulanması gerçekçi olmayacaktır. Esasında IBA Kılavuzunun ICSID tahkimi bakımından görülen hakemin reddi kararlarına uygun olmayışı dikkate alınarak halihazırda çalışmaları devam eden bir Taslak Davranış Kuralları çalışması bulunmaktadır. Bu çalışma IBA Kılavuzunun yerini alma ve hakemlerin bağımsızlığı, tarafsızlığı, ifşa yükümü gibi konuları detaylandırıyor olma bakımından çok önemli hususiyetler arz etmektedir. Sözkonusu çalışmada göze çarpan tek eksik husus, IBAKılavuzunda 
olduğu hakemlere ifşa etmelerini gerektirmeyecek durumları örnek olarak göstermemesi ve bir anlamda hakemler için ifşa yükümü bakımından 'güvenli bölge' tesis etmeyişidir.

Son olarak, çalışmanın son kısmında incelenen en sık karşılaşılan ret sebepleri bakımından ICSID kararlarında bazı konularda istikrarlı kararların verildiği görülmekle birlikte bazı konularda verilen kararların hatalı olduğu ve gerçeklikle örtüşmediği görülmektedir. Bu bakımdan hakemin daha önce bir taraf aleyhine başka bir tahkimde karar vermiş olmasının tek başına ret sebebi olmayacağı zira her bir tahkim yargılamasının birbirinden farklı hususiyetler taşıdığı veya hakemin bir tarafça birden fazla kez atanmış olmasının ret sebebi olmayacağı yönünde istikrarlı bir şekilde karar verilmektedir. Ancak yine istikrarlı bir şekilde hakemin daha önceden uyuşmazlık konusu hakkında akademik yayın yapmış olmasının eğer somut olarak uyuşmazlığa herhangi bir atıf yoksa ret sebebi olmayacağı yönünde istikrarlı bir şekilde verilen kararların tekrar gözden geçirilmesi gerekmektedir. Zira ICSID tahkiminde tartışlacak konu havuzu dardır ve bir konuda görüşünü belirtmiş bir hakemin savunduğu pozisyonunu değiştirmesi beklemek pek olası değildir. Bu sebeple bu konuya ilişkin ret taleplerinin daha farklı bir şekilde incelenmesi daha gerçekçi gözükmektedir.

Sonuç olarak ICSID tahkiminde hakemin reddi konusunun mevcut haliyle tartışılmaya devam edeceği açıktır. Söz konusu tartışmaların azalması ve hakemin reddi mekanizmasının daha işlevsel hale gelebilmesi için halihazırda olumlu kabul edilebilecek gelişmeler muhafaza edilmeli ve istikrarlı şekilde uygulanmalı; eksik yönler bakımından ise iyileştirme önerileri dikkate alınmalidir.

\section{KAYNAKÇA}

\section{Birincil Kaynaklar}

\section{Kararlar}

ICSID Case No. ARB/97/3 Compañía de Aguas del Aconquija S.A. \& Vivendi Universal v. Argentine Republic DECISION ON THE CHALLENGE TO THE PRESIDENT OF THE COMMITTEE [2001]

ICSID CASE No. ARB/00/9 GENERATION UKRAINE, INC., and UKRAINE [2003] Award

ICSID Case No. ARB/07/16 ALPHA PROJEKTHOLDING GMBH and UKRAINE [2010] Decision on Respondent'sProposal to Disqualify Arbitrator Dr. Yoram Turbowicz

ICSID Case No ARB/10/5 Tidewater Inc v The Bolivarian Republic of Venezuela [2010] DECISION ON CLAIMANTS' PROPOSAL TO DISQUALIFY PROFESSOR BRIGITTE STERN 
IIIIIIIIII!

ICSID Case No. ARB/07/26 URB ASER S.A.and Argentine Republic [2010] Decision on Proposal to Disqualify Professor Campbell MacLachlan

ICSID Case No. ARB/06/19 Nations Energy Corporation v Republic of Panama [2011] Decision on the Proposal to Disqualify Dr. Stanimir A. Alexandrov

ICSID Case No. ARB/10/14 OPIC Karimum Corporation v. The Bolivarian Republic of Venezuela [2011] DECISION ON THE PROPOSAL TO DISQUALIFY PROFESSOR PHILIPPE SANDS

ICSID Case No. ARB 11/29 GETMA INTERNATIONAL and others v Republic of Guinea [2012] Decision on the Proposal for Disqualification of Arbitrator Bernardo M. Cremades

ICSID Case No. ARB 07/30 ConocoPhilips and others v Bolivarian Republic of Venezuela [2012] Decision on the Proposal for Disqualify L.Yves Forther

ICSID Case No. ARB/12/20 BLUE BANK INTERNATIONAL \& TRUST (BARBADOS) LTD. and BOLIVARIAN REPUBLIC OF VENEZUELA [2013] DECISION ON THE PARTIES' PROPOSALS TO DISQUALIFY A MAJORITY OF THE TRIBUNAL

ICSID Case No. No. ARB/12/38 Repsol SA v Republic of Argentina [2013] Decision on the Proposal for Disqualification of Arbitrators Francisco Orrego Vicuna and Claus von Wobeser

ICSID Case No. ARB/08/5 BURLINGTON RESOURCES, INC. and REPUBLIC OF ECUADOR [2013] DECISION ON THE PROPOSAL FOR DISQUALIFICATION OF PROFESSOR FRANCISCO ORREGO VICUÑA

ICSID Case No. ARB/13/13 Caratube International Oil Company LLP v. Republic of Kazakhstan [2014] DECISION ON THE PROPOSAL FOR DISQUALIFICATION OF Mr. Bruno Boesch

ICSID Case No. ARB/07/5 ABACLAT AND OTHERS and ARGENTINE REPUBLIC [2014] DECISION ON THE PROPOSAL TO DISQUALIFY A MAJORITY OF THE TRIBUNAL

ICSID Case No. ARB/17/34 RAIFFEISEN BANK INTERNATIONAL AG and REPUBLIC OF CROATIA [2018] DECISION ON THE PROPOSAL TO DISQUALIFY STANIMIR ALEXANDROV

ICSID Case No. ARB/19/4 CANEPA GREEN ENERGY OPPORTUNITIES I, S.Á R.L. AND CANEPA GREEN ENERGY OPPORTUNITIES II, S.Á R.L. CLAIMANTS and KINGDOM OF SPAIN [2019] DECISION ON THE PROPOSAL T DISQUALIFY MR. PETER REES QC

ICSID Case No. ARB/19/20 AYAT NIZAR RAJA SUMRAIN and STATE OF KUWAIT [2020] DECISION ON THE CLAIMANTS' PROPOSAL TO DISQUALIFY PROF. ZACHARY DOUGLAS AND MR. V. V. VEEDER 
ICSID Case No. ARB/17/5 EUGENE KAZMIN and REPUBLIC OF LATVIA [2020] DECISION ON THE PROPOSAL TO DISQUALIFY ALL MEMBERS OF THE TRIBUNAL

ICSID Case No. ARB/15/45 LANDESBANK BADEN-WÜRTTEMBERG ET AL. and KINGDOM OF SPAIN [2020] DECISION ON THE SECOND PROPOSAL TO DISQUALIFY ALL MEMBERS OF THE TRIBUNAL

ICSID Case No. ARB/13/36 EISER INFRASTRUCTURE LIMITED AND ENERGÍA SOLAR LUXEMBOURG S.À R.L. Claimants and KINGDOM OF SPAIN [2020] DECISION ON THE KINGDOM OF SPAIN'S APPLICATION FOR ANNULMENT

ICSID Case No. ARB/15/25 KS INVEST GMBH and KINGDOM OF SPAIN [2020] DECISION ON THE PROPOSAL TO DISQUALIFY PROF. KAJ HOBÉR

ICSID Case No. ARB/15/45 LANDESBANK BADEN-WÜRTTEMBERG ET AL. and KINGDOM OF SPAIN [2020] DECISION ON THE SECOND PROPOSAL TO DISQUALIFY ALL MEMBERS OF THE TRIBUNAL

ICSID Case No. ARB/19/30 VM SOLAR JEREZ GMBH and KINGDOM OF SPAIN [2020] DECISION ON THE PROPOSAL TO DISQUALIFY PROF. DR. GUIDO SANTIAGO TAWIL

PCA CASE No 2013-09 CC/DEVAS (MAURITIUS) LTD and THE REPUBLIC OF INDIA [2013] Decision on the Respondent's Challenge to the Hon. Marc Lalonde as Presiding Arbitrator and Prof. Francisco Orrego Vicuna as Co Arbitrator

\section{Sözleşmeler ve Kurumsal Düzenlemeler}

Arbitration Rules of the Arbitration Institute of the Stockholm Chamber of Commerce [2017]

Code of Conduct for Adjudicators in Investor-State Dispute Settlement (version two) [2021]

Convention on the Settlement of Investment Disputes Between States and Nationals of Other States (ICSID Convention [1966]

ICSID Convention Arbitration Rules [2006]

ICC Arbitration Rules [2021]

LCIA Arbitration Rules [2014]

UNCITRAL Arbitration Rules [2013] 
IIIIIIIIIII

\section{İkincil Kaynaklar \\ Kitaplar}

Akıncı Z, Milletlerarası Tahkim (5.Bask1, Vedat Kitapçı1ık 2020)

Born B G, International Commercial Arbitration (3. Bask1, Wolters Kluwer 2020)

Croft C, Kee C ve Waincymer J, A Guide to UNCITRAL Arbitration Rules (Cambridge University Press 2013)

Cleis N M, The Independence and Impartiality of ICSID Arbitrators: Current Case Law, Alternative Approaches, and Improvement Suggestions (Brill 2017)

Kayalı D, Milletlerarası Ticari Tahkimde Hakemlerin Bağımsızlığı ve Tarafsızlı $\breve{g}$ (Doktora Tezi, Ankara Üniversitesi Sosyal Bilimler Enstitüsü Özel Hukuk Anabilim Dali 2015)

Scheurer H C ve diğerleri, The ICSID Convention: A Commentary (2. Bask1, Cambridge University Press 2009)

\section{Makaleler}

Bishop D ve Reed L, 'Practical Guidelines for Interviewing, Selecting and Challenging Party-Appointed Arbitrators in International Commercial Arbitration (1998) 14(4) ARBITRATION INTERNATIONAL 395

Bottini G, 'Should Arbitrator Live on Mars- Challenge of Arbitrators in Investment Arbitration' (2009) 32 Suffolk Transnat'l L Rev 341

Daele K, Challenge and Disqualification of Arbitrators in International Arbitration (Kluwer Law International 2012)

Daele K, 'Saint Gobain v Venezuela and Blue Bank v Venezuela: The Standard for Disqualifying Arbitrators Finally Settled and Lowered' (2014) 29(2) ICSID Review 296

Fry D J ve Stampalija I J, 'Forged Independence and Impartiality: Conflicts of Interest of International Arbitrators in Investment Disputes' (2014) 30(2) Arbitration International 189

Giorgetti C, 'Challenges of International Investment Arbitrators: How Does It Work, and Does It Work?' (2013) 7(2) World Arbitration \& Mediation Review 303

Hwang M ve Lim K, 'Issue Conflict in ICSID Arbitrations' (2011) 8(5) Transnational Dispute Management

Karaca A H," 'Milletlerarası Tahkimde Hakemin Reddi Sebebi Olarak Hakemin Tarafsızlığını ve Bağımsızlığını Ortadan Kaldıran Haller' (2015) 21(1) Marmara Üniversitesi Hukuk Fakültesi Hukuk Araştırmaları Dergisi 205 
Kinnear M, 'Challenge of Arbitrators at ICSID—An Overview' (2014) 108 The Effectiveness of International Law 412

Lalonde M, 'Chapter 46: Quo Vadis Disqualification?', in Meg Kinnear ve diğerleri. (eds), Building International Investment Law: The First 50 Years of ICSID, (Kluwer Law International 2015)

Landolt P, 'The IBA Guidelines on Conflicts of Interest in International Arbitration: An Overview' (2005) 22(5) 409

Malintoppi L ve Yap A, 'Challenges of Arbitrators in Investment Arbitration: Still Work in Progress?' in Katia Yannaca Small (ed), Arbitration Under International Investment Agreements: A Guide to Key Issues (2. Bask1 Oxford University Press 2018)

Özbek S M, 'Tahkim Yargılamasında Hakemin Reddi' (2021) 8(1) Türkiye Noterler Birliği Hukuk Dergisi 35

Sheppard A, 'Arbitrator Independence in ICSID Arbitration' in Christina Binder, Ursula Kriebaum, August Reinisch ve Stephan Wittich, International Investment Law for the 21st Century: Essays in Honour of Christoph Schreuer (Oxford University Press 2009)

Şahin A ve Özsu G, 'Yatırımcı Devlet Uyuşmazlık Çözüm Sistemi’nin (ISDS) Reformu Bakımından Önemli Bir Adım: Taslak Etik Kurallar' (2021) 12(46) Türkiye Adalet Akademisi Dergisi 477

Walsh W T ve Teitelbauma R, 'The LCIA Court Decisions on Challenges to Arbitrators: An Introduction' (2011) 27(3) Arbitration International 283

\section{Diğer İnternet Kaynakları}

Finkel K, 'Arbitrator challenges: a practical guide' (2020) <https:// globalarbitrationnews.com/arbitrator-challenges-a-practical-guide/ $>$ erişim 30.05.2021

ICSID, 'Suggested Changes to the ICSID Rules and Regulations' (2005), $<$ https://icsid.worldbank.org/sites/default/files/Suggested\%20Changes\%20 to \%20the \%20ICSID\%20Rules\%20and\%20Regulations.pdf/> erişim 30.05 .2021

'Proposals for Amendment of the ICSID Rules Working Paper 4' (2020) $<$ https://icsid.worldbank.org/sites/default/files/amendments/WP_4_Vol_1_ En.pdf> erişim 30.05.2021

'CODE OF CONDUCT - BACKGROUND PAPERS: REPEAT APPOINTMENTS' (2021), <https://icsid.worldbank.org/sites/default/ files/Background_Papers_Repeat_Appointments_final_25.2.2021.pdf $>$ erişim30.05.2021 
IIIIIIIIIII-

'CODE OF CONDUCT - BACKGROUND PAPERS: Double Hatting' $(2021)<$ https://icsid.worldbank.org/sites/default/files/Background_Papers Double-Hatting_(final)_2021.02.25.pdf $>$ erişim 30.05.2021

'CODE OF CONDUCT - BACKGROUND PAPERS ISSUE CONFLICT' $(2021)<$ https://icsid.worldbank.org/sites/default/files/Background_Papers_ Issue_Conflict_Final_2.26.2021.pdf $>$ erişim 30.05.2021

ICSID ve UNCITRAL, 'DRAFT CODE OF CONDUCT Comments by State/ Commenter' (2021) <https://icsid.worldbank.org/sites/default/files/Code $\% 20$ of $\% 20$ Conduct $\% 20-\% 20$ Comments $\% 20$ by $\% 20$ State-Commenter $\% 20-\% 20$ Updated\%2001.14.21.pdf> erişim 30.05.2021

Ipp A, Carè R ve Dubeshka V, 'SCC Board Decisions on Challenges to Arbitrators 2016-2018' (2019) <https://sccinstitute.com/media/795278/sccpractice-note_scc-decisions-on-challenges-to-arbitrators-2016-2018.pdf $>$ erişim 30.05.2021.

Liebkind A, 'SCC Board Will Provide Reasoned Decisions on Arbitrator Challenges' (2017) <https://globalarbitrationnews.com/scc-board-willprovide-reasoned-decisions-arbitrator-challenges/> erişim 30.05.2021

Moses M, 'The Role of the IBA Guidelines on Conflicts of Interest in Arbitrator Challenges' (2017) <http://arbitrationblog.kluwerarbitration. com/2017/11/23/role-iba-guidelines-conflicts-interest-arbitrator-challenges/> erişim 30.05.2021

Mourre A, 'Are unilateral appointments defensible? On Jan Paulsson's Moral Hazard in International Arbitration', Kluwer Arbitration Blog, October 5, 2010, $<$ http://arbitrationblog.kluwerarbitration.com/2010/10/05/are-unilateralappointments-defensible-on-jan-paulssons-moral-hazard-in-internationalarbitration/> erişim 30.05.2021.

Sucharitkul V, 'ICSID and UNCITRAL Draft Code of Conduct: Potential Ban on Multiple Roles Could Negatively Impact Gender and Regional Diversity, as well as Generational Renewal' (2020)<http://arbitrationblog.kluwerarbitration. com/2020/06/20/icsid-and-uncitral draft-code-of-conduct-potential-ban-onmultiple-roles-could-negatively-impact gender-andregional-diversity-as-wellas-generational-renewal/> erişim 30.05.2021.

Prokic D, 'The Annulment of Eiser v. Spain: A Call for Improvements to the System?' May 6 2021, <http://arbitrationblog.kluwerarbitration. com/2021/05/06/the-annulment-of-eiser-v-spain-a-call-for-improvements-tothe-system/ > erişim 30.05.2021 